\title{
Ant diversity studies in Acre: what we know and what we could do to know more?
}

\section{Estudos de diversidade de formigas no Acre: o que sabemos e o que devemos fazer para saber mais?}



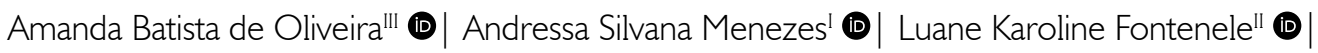 \\ Elder Ferreira Moratol (D) Marco Antônio Oliveiral \\ Universidade Federal do Acre. Rio Branco, Acre, Brasil \\ "Universidade Federal de Lavras. Lavras, Minas Gerais, Brasil \\ "'Universidade Federal do Amazonas. Manaus, Amazonas, Brasil \\ IV Universidade Federal de Viçosa. Florestal, Minais Gerais, Brasil
}

\begin{abstract}
Brazil counts with one the largest ant diversity in the world. But, given its continental dimension and uneven scientific development process, there are still several gaps in the knowledge of this biodiversity. This fully applies to research on ant diversity in the state of Acre, southwestern Brazilian Amazon. Since 2014, in Acre, ants are being sampled by Rede BIA project, which aims to cover this gap. Thus, our main goal is to present the status of ant diversity studies in Acre regarding their progress and their contribution to the ant fauna knowledge, based on scientific papers and grey literature. We found 17 studies to Acre, which encompass a time range of 10 years, and a total of 338 species recorded. The studies are concentrated mainly in the southern and eastern parts of the state. Ground pitfall trap is the most used sampling technique. We point out that adding more sites to Rede BIA's collecting efforts, plus focusing samplings in poorly studied habitats and ecosystems, especially in the western and eastern parts of the state will provide a lot of new data on ant species occurrence to Acre and to Brazil.
\end{abstract}

Keywords: Amazon. Biodiversity. Distribution. Formicidae.

Resumo: O Brasil está entre as regiões com maior diversidade de formigas do mundo, porém, devido à sua dimensão continental e a um processo desigual de desenvolvimento científico, ainda há muitas lacunas de conhecimento sobre sua biodiversidade. Isto se aplica plenamente às pesquisas sobre formigas no estado do Acre, no sudoeste da Amazônia brasileira. Desde 2014, no Acre, formigas têm sido coletadas pelo projeto Rede BIA, cujo objetivo é aumentar o conhecimento sobre a biodiversidade de insetos na Amazônia brasileira. Assim, o objetivo desta pesquisa é apresentar um panorama sobre os estudos de diversidade de formigas no Acre em relação ao nível de desenvolvimento e sua contribuição para o conhecimento da fauna de formigas, baseando-se em artigos científicos e literatura cinza. Foram levantados 17 estudos para o Acre realizados nos últimos dez anos, os quais registraram 338 espécies de formigas. Os estudos estão principalmente agrupados nas partes sul e leste do Acre. Armadilha de queda na superfície do solo é a técnica de coleta mais utilizada. Entendemos que o acréscimo de pontos de coleta ao projeto Rede BIA, junto com coletas em habitats e ecossistemas pouco estudados fornecerão grande quantidade de novos dados e registros de ocorrência de espécies de formigas para o Acre e o Brasil.

Palavras-chave: Amazônia. Biodiversidade. Distribuição. Formicidae.

SCHMIDT, F. A., M. M. S. COSTA, F. MARTELLO, A. B. OLIVEIRA, A. S. MENEZES, L. K. FONTENELE, E. F. MORATO \& M. A. OLIVEIRA, 2020. Ant diversity studies in Acre: what we know and what we could do to know more? Boletim do Museu Paraense Emílio Goeldi. Ciências Naturais 15(1): 113-134. DOI: http://doi.org/10.46357/bcnaturais.v15i1.235.

Autor para correspondência: Fernando Augusto Schmidt. Universidade Federal do Acre. BR-364, km 04 - Bairro Distrito Industrial. Rio Branco, AC, Brasil. CEP 69920-900 (schmidt.fa@gmail.com).

Recebido em 13/12/2019

Aprovado em 28/03/2020

Responsabilidade editorial: Rony Peterson Santos Almeida
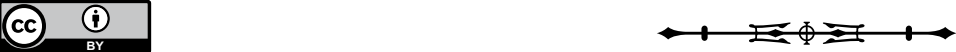


\section{INTRODUCTION}

Brazil is among the most diverse ant regions in the world (Dunn et al., 2007) with approximately 1,500 recorded species (AntWiki, 2019) and, in a conservative estimation, around 1,000-2,000 others ant species to be recorded in its territory (Baccaro et al., 2015). This high diversity, allied to the great importance of this insect group to essential ecosystem process (Del Toro et al., 2012), the pest status of several species in agroecosystem and urban environments as well as its refined response to environmental changes (which make ants excellent bioindicator group) (Philpott et al., 2010), turns Brazil as a pole of ant research in the world. Although, given its continental dimension and uneven scientific development process, there are several lacks on the knowledge of Brazilian biodiversity and its process, regardless of the group of organisms (Lewinsohn \& Prado, 2005), especially in less economically developed areas, which consequently contain fewer universities and research institutions. This fully applies to biodiversity researching in the state of Acre, southwestern Brazilian Amazon.

Acre is located in a transition area between the eastern Andes mountain chain and Amazonian lowlands (Souza et al., 2003), representing 4\% of the Brazilian Amazon (Acre, 2010). The diversity of soil types, reliefs, climate and river basins offer to the region a huge heterogeneity of ecosystems and landscapes that harbor exuberant biodiversity (Acre, 2010). In this way, Acre has a great variety of vegetation types, wherein open rainforest, with palm trees, bamboo and lianas occupies the most of the state (80\%), although small patches of close rainforest and white-sand vegetation can be found mainly in northwestern portion (Acre, 2010). Although, Acre has around $80 \%$ of original vegetation conserved due to a diversified system of protected areas, in the last four decades an intensive process of land occupation, mainly pasture implementation (Acre, 2010) has led to high levels of deforestation and fragmentation (INPE, 2019; Mapbiomas, 2019).

In general, biodiversity studies in Acre have been conducted essentially by researching initiatives of Universidade Federal do Acre (UFAC) and it can be divided into two historical periods: (i) beginning of 90's (20th century) and (ii) 2002 up to nowadays. In the beginning of 90's most professors of Biology and Biodiversity area developed their doctorate thesis, in which sites in Acre where used as sampling areas leading to expressive contribution to biodiversity knowledge of several groups, such as phytoplankton, plant, orchid bees, frogs, snakes and mammals (UFAC, 2020). In 2002, UFAC was authorized to open the graduate course in Ecology and Natural Resources Management at master's degree and until nowadays dissertations projects developed in this course have been the main source of studies on Biodiversity in Acre (UFAC, 2020). Additionally, the Ecological and Economic land use zoning of Acre (Acre, 2010), with the engagement of researchers of UFAC also made contributions to biodiversity survey in Acre.

In this context, the biodiversity of some groups is wellknown, for example trees-shurbs (Daly \& Silveira, 2008) frogs (Souza, 2009), snakes (Bernarde, 2012; Bernarde et al., 2017) and birds (Guilherme, 2016), however, for many others groups the studies are very scarce and at an incipient level (Drumond, 2005), which ants are one of these groups poorly searched. Although, sporadic ant samplings have been done (e.g. inclusion of ant species records on ant genera revision and on entomological collections of museums) (Kempf, 1968; De Andrade \& Urbani, 1999; Ward, 1999; Bolton, 2020), the historic of ant diversity studies in Acre, with standard ecological questions and sampling designing, is much recent, beginning ten years ago (Oliveira, M. et al., 2009) and until the moment only more eight papers have been published. Most of these studies report the answer of ant assemblages to land use shifting, wildfire disturbance, selective logging forest management and forest regeneration (e.g. Oliveira, M. et al., 2011; Barlow et al., 2012; Miranda et al., 2017; Oliveira, A. \& Schmidt, 2019). In order to improve this effort, in 2014, Elder Ferreira Morato and Fernando Augusto Schmidt, researchers of UFAC, joined the network project Insect Biodiversity in Amazon (Rede BIA), leaded by researchers from Instituto Nacional de Pesquisas da Amazônia (INPA), which the main aim is to increase the number of sampling sites of several

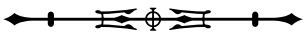


insects groups within Brazilian Amazon. Until this moment, this project has been sampling orchid bees (tribe Euglissini) and ants in 16 sites on the major five river basins of the Acre state (i.e. Acre, Purus, Tarauacá, Envira and Purus).

Thus, our main aim is to draw a picture of the status of ant diversity studies in Acre regarding to their development level and their contribution to the ant fauna knowledge based on reports present in published scientific papers and grey literature. Specifically, we addressed the following questions: i) How many species and morphospecies have been reported in ant diversity studies?; ii) Where these studies have been carried out?; iii) What types of ant sampling techniques have been used?; iv) Which reference collection have been used on species identification process?; v) In which reference collection ant species vouchers have been deposited? vi) Which areas of Acre are most relevant for future sampling?; and vii) How ant sampling sites of Rede BIA has achieved these areas of future sampling relevance in Acre? Based on the answer to these questions, we presented options to fill the lacks on ant diversity researching in Acre.

\section{MATERIAL AND METHODS}

Regardless, that prominent Brazilian and foreign researching institutions and studies on genera revision offer records about ant species occurrence in Acre (e.g. Kempf, 1968; De Andrade \& Urbani, 1999; Ward, 1999; Bolton, 2020), to draw a picture of the status of ant diversity studies in Acre, we only used information present in scientific papers and grey literature that reports ant surveys and ecological studies. We used this kind of reports because they describe studies that were carried out specifically to survey the ant fauna or answer ecological questions regarding ant assemblages in sites of Acre, which help us to achieve our main aim, draw a picture of the status of ant diversity studies in Acre.

We obtained information about ant diversity studies at three ways: (i) searching published scientific papers in literature databases; (ii) consults to scientific papers on our private bibliography and (iii) accessing the institutional repository of monographs and dissertations in Forestry
Engineering under graduation course and Ecology and Natural Resources Management graduate course, both from UFAC (here mentioned as grey literature). The searching of published scientific papers was done in Science direct, Scielo and Web of Science, using the keywords "myrmecofauna", "Acre", "ants", "Formicidae" and "Southwestern Amazonia". We also checked the Google Scholar database, for papers published in Portuguese using the same keywords mentioned above, but in Portuguese.

For each study surveyed, we extracted the following data: (i) year of publication; (ii) study type; (iii) geographical coordinates; (iv) total number of species sampled; (v) species list; (vi) sampling technique; (vii) reference collection used for species identification; (viii) entomological/myrmecological collection where the ant species vouchers have been deposited. To compile a general list of species reported in the studies, we followed the ant classification available in AntCat (Bolton, 2020). This list was compared to the ant species list present in AntMaps.org (Janickiet al., 2016), which has until the moment has 317 ant species recorded to Acre. This comparison was used to evaluate the contribution of ant diversity studies to the ant fauna knowledge of Acre.

To verify how distributed are the ant sampling sites reported in the literature surveyed (papers and grey literature), we plotted all their geographical coordinates in Acre map. Based on these sampling sites reported in the literature surveyed, we accessed the relevance of ant sampling for further studies in each area of $1 \mathrm{~km}^{2}$ of Acre, as its environmental dissimilarity from sites already sampled in the literature, considering eight environmental variables: altitude, soil type and six bioclimatic variables (annual mean temperature, the maximum temperature of warmest month, minimum temperature of coldest month, annual precipitation, precipitation of wettest month and precipitation of driest month). These variables are a set of rasters layers with a spatial resolution of $1 \mathrm{~km}^{2}$ available on the AmbData site (Amaral et al., 2013), for soil types and altitude, and WorldClim site (Fick \& Hijmans, 2017), for bioclimatic variables. Continuous variables were previously standardized by z-score to avoid the bias of 
variables with larger values (Legendre \& Legendre, 2012). Regarding these variables, for each area of $1 \mathrm{~km}^{2}$, we calculated the mean of enviromental dissimilarity from ant sampling sites (literature surveyed), based on Gower distance (Legendre \& Legendre, 2012). After that we normalize all values from 0 to 1, performing a Min-Max normalization (Patro \& Sahu, 2015), in a way that values near to 0 represent areas highly similar, whereas values near to 1 represent areas environmentally very different from areas where ants have been collected (in terms of the environmental variables). Thus, it resulted in a raster containing a gradient of ant sampling relevance to Acre. Afterward, we extracted relevance of ant sampling for the geographical coordinates of Rede BIA sites to verify the sampling relevance of the sampling sites of this project to the ant diversity in Acre. Sampling relevance was calculated under programming software R v 3.6.2 (R Development Core Team, 2019) using packages vegan (Oksanen et al., 2019), raster (Hijmans et al., 2019) and rgdal (Bivand et al., 2019).

\section{RESULTS}

We surveyed 17 studies, which nine were published papers and eight were grey literature (four undergraduatemonographs and four master-dissertation). The time range of the studies is very recent, only the last 10 years (20092019). Species lists are present in 15 studies. Regarding to the ant fauna sampled in these 17 studies, a total of 338 species have been reported to Acre, which belong to nine subfamilies and 66 genera (Appendix). The most speciose subfamily was Myrmicinae (162), followed by Formicinae and Ponerinae (both with 47), Dolichoderinae (23), Dorylinae, Ectatomminae and Pseudomyrmecinae (19 each), Paraponerinae and Heteroponerinae (both with only one species). Among the genera, Pheidole (Myrmicinae) and Camponotus (Formicinae) had the highest number of species, with 38 and 35 species, respectively. In the species lists presented in the studies, the mean percentage of ants sorted in morphospecies was $44.6 \%$ (min.: 16.1 - max.: 75.9) (Table 1).

Regarding to Acre, comparing the ant fauna present in the surveyed studies with the ant fauna reported in
AntMaps.org (Janicki et al., 2016), the two data set share 278 ant species. Our dataset presents 60 exclusive species and AntMaps.org dataset has 51 exclusive species. Accounting these values result in 389 species to Acre until the moment.

The ant samplings reported in the surveyed studies seems spatially biased and aggregated - concentrated mainly in the southern and eastern part of the State and nearby to Rio Branco city, the capital of Acre (Figure 1). Most of the studies in the eastern region was carried out in Fazenda Experimental Catuaba, one of natural reserves of UFAC. Aggregate samples in the southern region belong to a single study in the Extractive Reserve Chico Mendes in Assis Brasil. The remaining sampling sites reported in the studies have a sparse distribution throughout to Rio Acre basin, except to a single site in Rio Purus basin in State Park Chandless (the most western point in Figure 1).

The ants in Acre have been collected by a diversified range of samplings techniques (nine in total), although ground pitfall trap is markedly the most used (Figure 2). In total seven ant reference collections have been used to ant identification to species level, of which collections of UFAC, Universidade Federal do Paraná (DZUP) and Centro de Pesquisas do Cacau (CPDC) are the three most consulted (Figure 3). Regarding to voucher deposits, the most part of ant species sampled in diversity studies in Acre have been deposited in six entomological/myrmecological collections, which collections of UFAC and CPDC have been the most used for voucher deposits (Figure 4). Regarding to voucher deposits at UFAC, these have been done in two different collections, Entomological Collection of Laboratório de Entomologia da UFAC and Entomological Collection of Laboratório de Ecologia de Insetos da UFAC.

The sampling sites of Rede BIA had an average sampling relevance of 0.46 ( $s d=0.2215$; $\min .: 0.05$ - max.: 0.84). Rede BIA sampling points with higher sampling relevance are from Rio Purus basin to western areas and sampling points with lower sampling relevance are throughout Rio Acre Basin, in southeastern portion (Figure 5). 
Table 1. Number of ant species reported in ant diversity studies developed in Acre, southwestern Brazilian Amazon, during the period of 2009 to 2019. Total number of ant species is partitioned in ants identified at species level and ants sorted at morphospecies. Number in brackets means percentage values. * Studies reported in published scientific papers.

\begin{tabular}{c|c|c|c}
\hline Study & Total number of ant species & Ants at species level & Ants at morphospecies \\
\hline Oliveira, M. et al. (2009)* & 276 & $200(72.5 \%)$ & $76(27.5 \%)$ \\
\hline Oliveira, M. et al. (2011)* & 276 & Non-informed & Non-informed \\
\hline Miranda et al. (2012)* & 267 & $224(83.9 \%)$ & $43(16.1 \%)$ \\
\hline Barlow et al. (2012** & Non-informed & Non-informed & Non-informed \\
\hline Miranda et al. (2013)* & 87 & $53(60.9 \%)$ & $34(39.1 \%)$ \\
\hline Santos, A. (2014) & 87 & $21(24.1 \%)$ & $66(75.9 \%)$ \\
\hline Denicol (2014) & 117 & $57(48.7 \%)$ & $60(51.3 \%)$ \\
\hline Miranda et al. (2017)* & 262 & $136(51.9 \%)$ & $126(48.1 \%)$ \\
\hline Menezes, A. B. (2017) & 67 & $20(29.9 \%)$ & $47(70.1 \%)$ \\
\hline Menezes, A. S. (2017) & 91 & $39(42.9 \%)$ & $52(57.1 \%)$ \\
\hline Silva (2017) & 178 & $70(39.3 \%)$ & $108(60.7 \%)$ \\
\hline Santos, R. \& Delabie (2018)* & 36 & $30(83.3 \%)$ & $6(16.7 \%)$ \\
\hline Costa (2018) & 216 & $114(52.8 \%)$ & $102(47.2 \%)$ \\
\hline Fontenele (2018) & 35 & $25(71.4 \%)$ & $10(28.6 \%)$ \\
\hline Oliveira, A. \& Schmidt (2019)* & 117 & $91(51.4 \%)$ & $11(19.6 \%)$ \\
\hline Miranda et al. (2019)* & 56 & $45(80.4 \%)$ & $78(62.9 \%)$ \\
\hline Sales (2019) & 124 & $46(37.1 \%)$ &
\end{tabular}

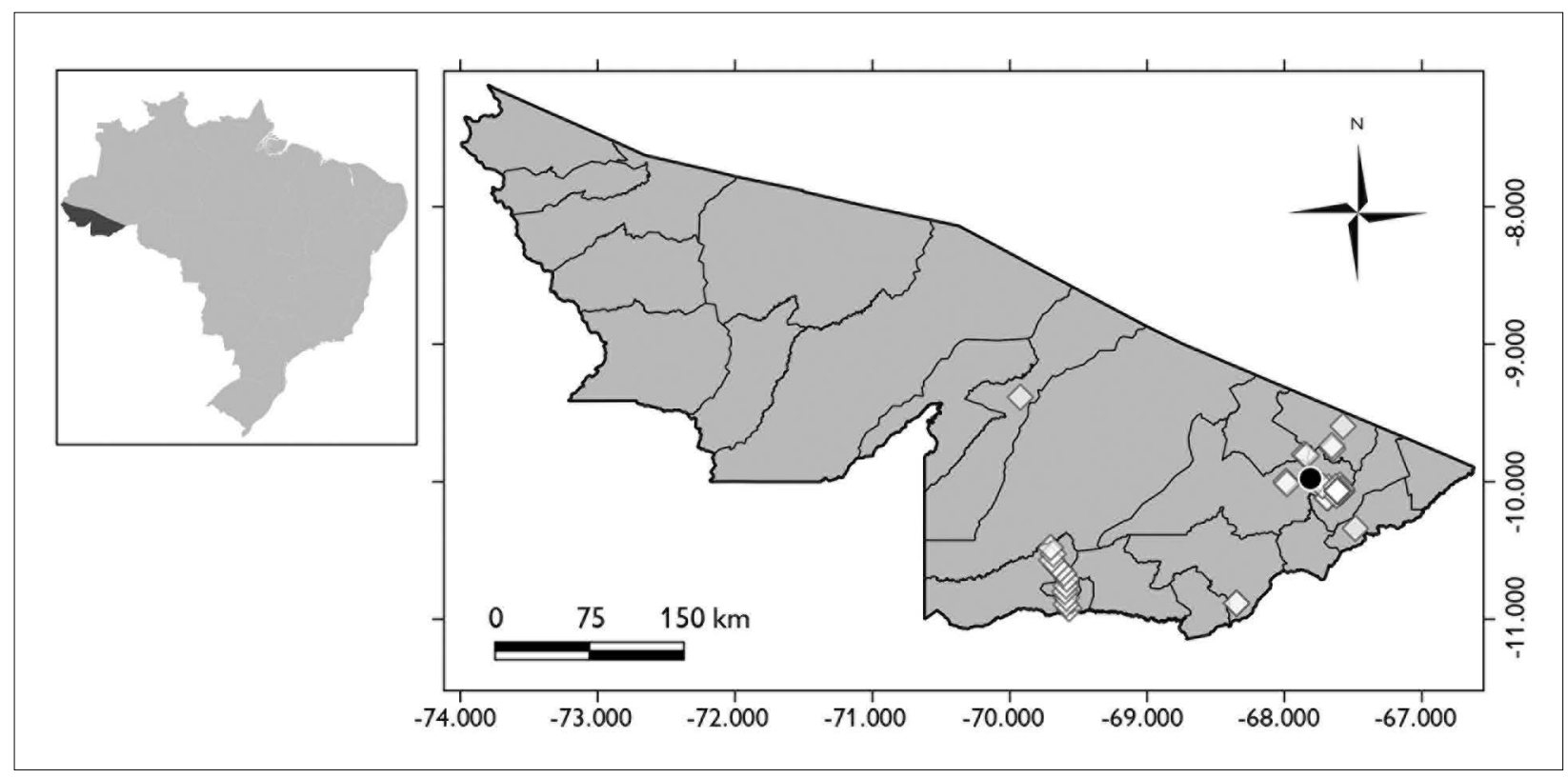

Figure 1. Sampling points of studies on ant diversity in Acre, southwestern Brazilian Amazon, from 2009 to 2019. Black point in map is Rio Branco, the capital of Acre. Map: F. Martello (2020). 


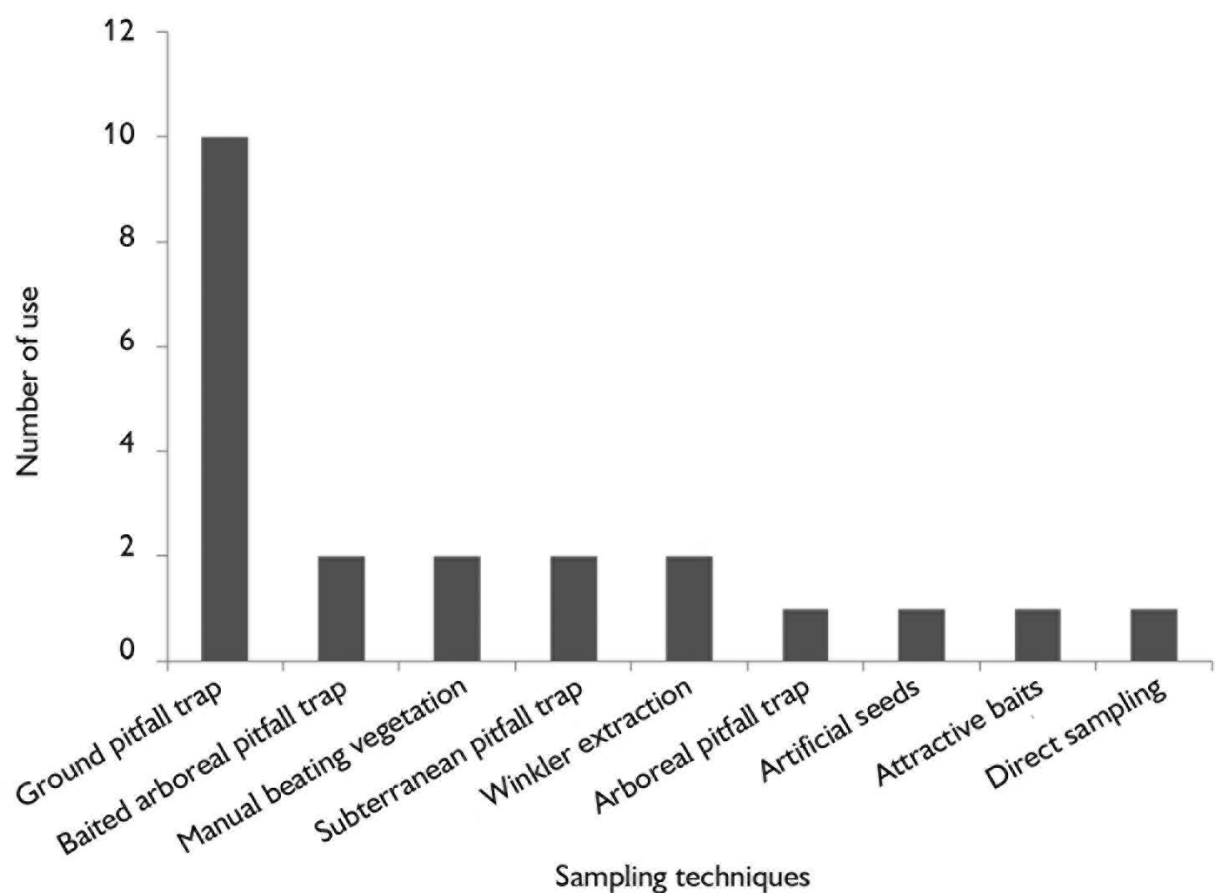

Figure 2. Sampling techniques used in the studies on ant diversity in Acre, southwestern Brazilian Amazon, from 2009 to 2019.

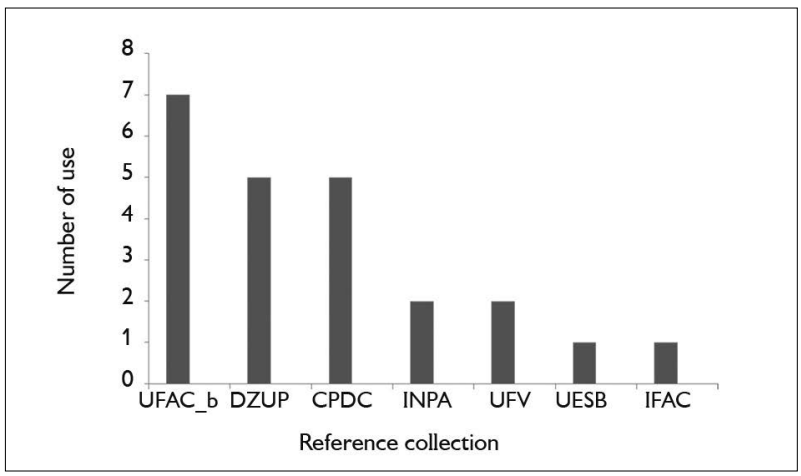

Figure 3. Reference collections used, by the survived studies, to identification at species level of ants sampled in Acre, southwestern Brazilian Amazon, from 2009 to 2019. UFAC b: Entomological Collection of Laboratório de Ecologia de Insetos da UFAC, Rio Branco, Acre, Brazil; DZUP: Padre Jesus Santiago Moure Entomological Collection - UFPR, Curitiba, Paraná, Brazil; CPDC: Collection of Centro de Pesquisas do Cacau - CPDC collection, CEPEC/CEPLAC, Itabuna, Bahia, Brazil; INPA: Entomological Collection of Instituto Nacional de Pesquisas da Amazônia, Manaus, Amazonas, Brazil; UFV: Regional Museum of Entomology of Federal University of Viçosa, Viçosa, Minas Gerais, Brazil; UESB: Universidade Estadual do Sudoeste da Bahia - UESB, Itapetinga, Bahia, Brazil; IFAC: Instituto Federal do Acre, Rio Branco, Acre, Brazil.

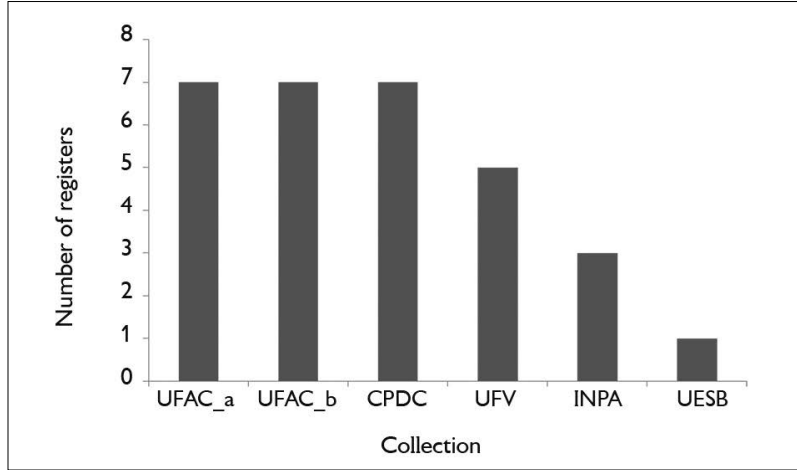

Figure 4. Entomological Collection used, by the survived studies, to deposit voucher specimens of ants sampled in Acre, southwestern Brazilian Amazon, from 2009 to 2019. UFAC_a: Entomological Collection of UFAC, Rio Branco, Acre, Brazil; UFAC b: Entomological Collection of Laboratório de Ecologia de Insetos da UFAC, Rio Branco, Acre, Brazil; CPDC: Collection of Centro de Pesquisas do Cacau - CPDC collection, CEPEC/ CEPLAC, Itabuna, Bahia, Brazil; UFV: Regional Museum of Entomology of Federal University of Viçosa, Viçosa, Minas Gerais, Brazil; INPA: Entomological Collection of Instituto Nacional de Pesquisas da Amazônia, Manaus, Amazonas, Brazil; UESB: Universidade Estadual do Sudoeste da Bahia - UESB, Itapetinga, Bahia, Brazil.

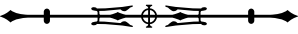




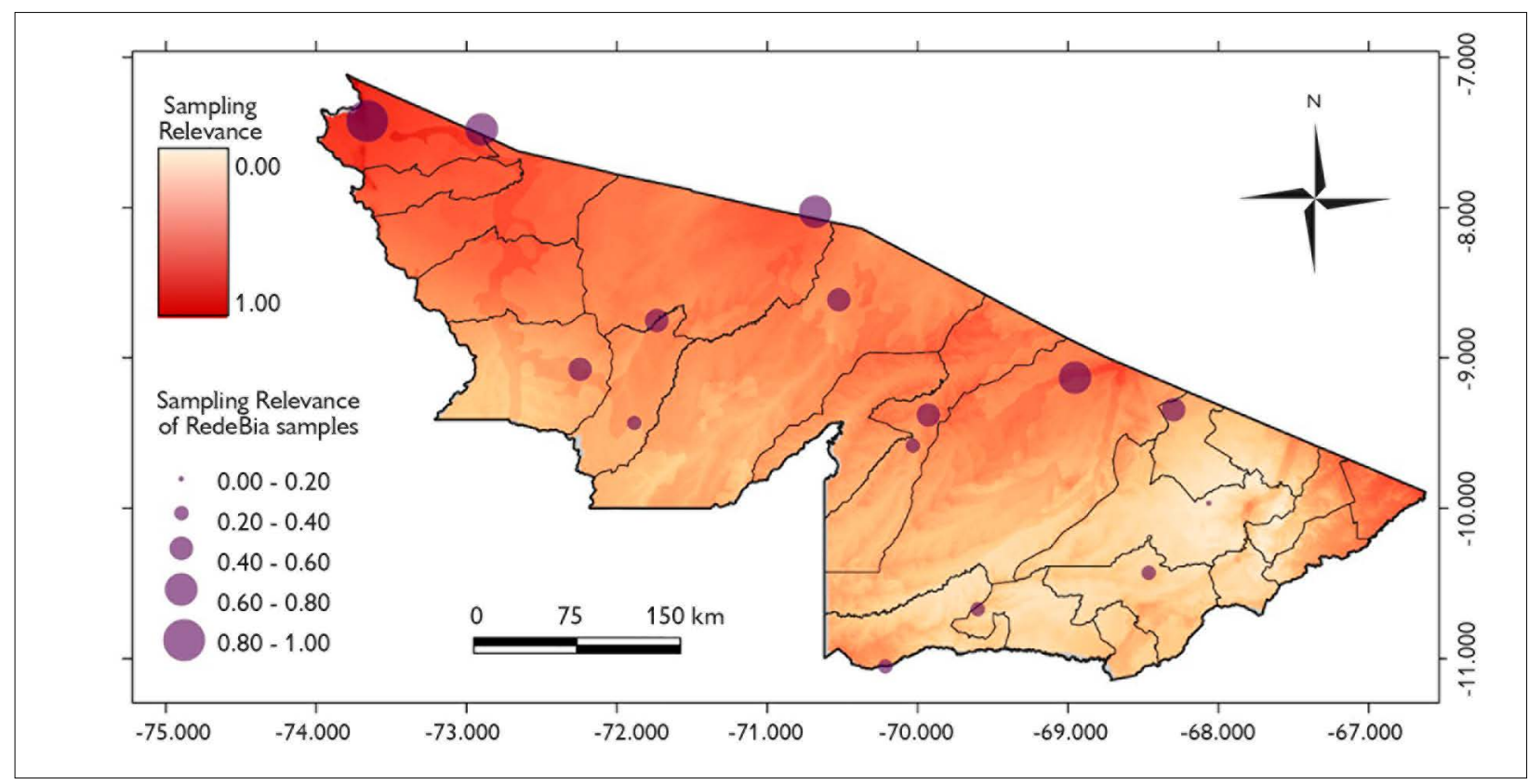

Figure 5. Map of ant sampling relevance of Rede BIA project to Acre, southwestern Brazilian Amazon. Map: F. Martello (2020).

\section{DISCUSSION}

Our results highlight that ant diversity studies in state of Acre are in a very incipient phase, considering the time ranging - only 10 years - and the low number of studies, in which almost the half has not published yet. However, these ant diversity studies plus records of Antmaps.org (Janicki et al., 2016) offer 389 ant species with occurrence to Acre. In order to reduce this gap of knowledge, Rede BIA effort have presented an efficient way to fill gaps on ant diversity sampling in Acre. In the subsequent sections, we present potential explanations to these results and offer suggestions to improve the researching of ant diversity studies in Acre state and their contribution to ant fauna knowledge.

The limited number of studies and the recent time on ant diversity exemplify a very critical issue to the Brazilian scientific development, that its unevenness regardless the field. While nine scientific papers would be the annual average of a single ant researcher in others Brazilian regions, this is the total amount of papers published on ant diversity along ten years for an entire region in Amazon. Besides that, other factors also aggravate this condition in
Acre, such as: i) the low appeal of ants and invertebrates to biodiversity researching, ii) the few number of research groups that have ants as main interest; iii) the limited success of biodiversity researchers on callings to financial support; iv) partnership with others researching at low frequency. Thus, in general, considering that Acre state, at least until now, has a well-preserved diversity and abundance of big-size animals, maybe they call more the attention of biodiversity researchers. Although, E. Morato had developed and advised studies on biodiversity of several insect groups, only in 2013, with the establishment of Ant Ecology group by F. Schmidt, UFAC had a researching group that have ant diversity studies as the main focus followed in 2012 by the researching group of P. Miranda in Instituto Federal do Acre (IFAC).

Nevertheless, in the last years, Brazilian Science has been struggling with frequent cuts on funding and student scholarships (Angelo, 2019; Andrade, 2019), which is compounded in less developed state such as Acre. In this way, Rede BIA probably is the unique project on insect biodiversity researching in Acre with financial support and in

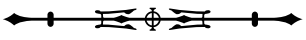


partnership with a major center of biodiversity researching in Brazilian Amazon (i.e. INPA) in the last 20 years, which ants and orchid bees have been included as main focus to the state.

The number of exclusive ant species reported in the studies surveyed (60) shows the high potential contribution of ant diversity studies to ant fauna knowledge in Acre. Considering that AntMaps.org (Janicki et al., 2016) only has data from five ant diversity studies of Acre (i.e. Oliveira, M. et al., 2009; Miranda et al., 2012, 2017; Santos, R. \& Delabie, 2018; Oliveira, A. \& Schmidt, 2019) highlights that most of these 60 ant species are reported in the grey literature (four undergraduate-monographs and four master-dissertation), which reinforce the necessity of these documents be published as scientific papers to effectively contribute to ant species distribution and diversity knowledge of Acre. Additionally, the number of exclusive species presented by AntMaps.org (Janicki et al., 2016) also highlights the valuable contribution of sporadic ant samplings, such as these present in museums and taxonomic revision that included ant species records to Acre. Finally, the two datasets (ant fauna present in our survey and this from AntMaps.org) can be viewed as complementary approaches that until the moment has reported 389 ant species to Acre, which can be higher because ant species records of museums and taxonomic revisions studies could be missing in AntMaps. org (Janicki et al., 2016) and were not considered by us.

The high percentage (44.6\%) of ants sorted only at morphospecies means a potential expressive adding to the number of ant species to Acre, even that several morphospecies may be assembled into one valid species. Another drawback to shift these high number of morphospecies into valid species is that most of these ants are Pheidole, Camponotus and Solenopsis, genera considered world-wide megadiverse (Wilson, 2003) - which makes their identification to species levels a difficult task because most of the ants are not formally described yet. Additionally, the huge amount of areas without sampling in Acre also reinforce that the number of ant species could be much higher than the number already known.
The low amount of sampling sites and their aggregate distribution also contribute to the number of ant species known to Acre. Such limitations on ant sampling in Acre is fully comprehensible considering that the most part of the studies are monographs and dissertation projects which have a short time for execution and limited financial resources hampering project in far sites that have been never sampled or few sampled. This aggregation of samples would also express the difficulty of access to various regions, both due to the lack of highways, which leads to high cost and time consuming for field expeditions (Schmidt \& Morato, personal communication). These spatial limitations can be evidenced by the high values sampling relevance values in various areas of Acre state (especially in the extreme west and east portions), also highlighting the diversity of environments in the state - which could further increase the number of ant species in Acre. In this way, initiative such as Rede BIA that has distributed sampling points throughout the state is a great opportunity to reveal new species records and descriptions to Acre state.

The much higher use of ground pitfall trap than others sampling techniques is another factor that has great influence in the number of ant species reported to Acre. Although, ground pitfall trap, due to its convenience and low time-cost, make it an efficient way to sample ants (Bestelmeyer et al., 2000) and arthropods in general (Brown \& Matthews, 2016), it captures essentially species that live and forage in soil surface. Studies that have included other ant habitats (e.g. underground soil layers) have provided the description of new species (Rabeling et al., 2008) and updates on species distribution records (Ryder Wilkie et al., 2007; Brandão et al., 2008; Schmidt et al., 2014). Thus, the knowledge of Acre ant fauna could be improved if future studies included other ant habitats than soil surface in their sampling designs.

Regardless the restrictions described above, one point that should be remarked is the collaboration of ant researchers from other regions of Brazil mainly in the process of species identification, once in Acre there is none formal 
ant taxonomist. Dr. J. Delabie from CEPLAC has made great contribution in this way. Additionally, since 2013 with the establishment of Ant Ecology group, UFAC have had a reference collection which species identification have been kindly provided by Dr. R. Feitosa and his group from UFPR.

Finally, based on our analyses of sampling relevance, Rede BIA potentially will provide a lot of new species records and hopefully description of new species of ants to Acre state because it has covered areas considered with high relevance for ant sampling. However, considering the expressive amount of areas with high values of sampling relevance on Acre, we believe that samples of Rede BIA will not comprises plentily ant diversity of Acre state and additional areas (e.g. all western border of Acre, the region between Tarauacá and Cruzeiro do Sul and the extreme eastern) must be focus on further studies, allowing a more representative survey of the ant fauna in Acre. Moreover, the addition of sampling points in these areas with high relevance for ant sampling will offer the establishment of a conspicuous and clear gradient of longitude, precipitation and forest cover, which is the baseline for studies on ant diversity gradients at a macroecological approach. Additionally, the high level of land use shifting (Mapbiomas, 2019), mainly forest into pastures means great threatens not only to ant diversity but to all biodiversity and ecological functions in the region, which makes biodiversity researching an essential issue (Acre, 2010).

\section{CONCLUSION: AVENUES TO FUTURE STUDIES}

Our literature survey shows that ant diversity studies are in an incipient phase, and that Acre state is a place that offer infinities opportunity for studies on ant diversity: there are many regions in Acre that are environmentally very different from those where there are ant samples. The adding of more sites to Rede BIA surely as well as encouraging new ant research projects in Acre certainly will provide a lot of new data on ant species occurrence to Acre and Brazil. Although most of expressive contributions on ant diversity of Acre are done by short-time projects, such as master dissertation projects, encouraging partnerships with researchers and students from other research institutes can bring new issues and more funds to exploit the poorly sampled areas of the state.

Regardless the focus of the projects, we would like to encourage ant researchers to include other habitats types than ground in their ant sampling, such as leaf litter, tree canopy and subterranean soil layers. Additionally, even with all financial restrictions, we also would like to call the attention for ecosystems few studied, such as close rainforest and white-sand vegetation in the western portion and the ecosystems associated to river sides that make up a conspicuous chronosequence of disturbance that also offer great opportunity to new data on ant diversity. Therefore, based on these recommendations and keeping the collaboration with myrmecologists of other regions in Brazil to have accurate reference collections, we believe that studies about ant diversity will place Acre in a marked position in Myrmecology world-map at a short-medium time.

\section{ACKNOWLEDGMENTS}

We thank the Graduate Program in Ecology and Natural Resource Management and the Forestry Engineering course at the Federal University of Acre for allowing the access to dissertations and monographs and thank P.N. Miranda for providing her thesis. The network project Insect Biodiversity in Amazon - Rede BIA (CNPq-Proc: 407631/2013-5) had financial support from MCTI/CNPq/ FNDCT Ação Transversal n 79/2013 - Redes Regionais de Pesquisa em Biodiversidade e Biotecnologia. We also thank the three referees for their comments and suggestions on previous version of the manuscript.

\section{REFERENCES}

ACRE, GOVERNO DO ESTADO, 2010. Programa estadual de zoneamento ecológico econômico do estado do acre, Fase II (escala 1:250,000): documento síntese: 1-152. Secretaria Estadual de Meio Ambiente, Rio Branco. 
AMARAL, S., C. B. COSTA, L. S. ARASATO, A. C. XIMENES \& C. D. RENNÓ, 2013. AMBDATA: variáveis ambientais para Modelos de Distribuição de Espécies (MDEs). Anais do Simpósio Brasileiro de Sensoriamento Remoto 15: 6930-6937.

ANDRADE, R. O., 2019. Brazil's budget cuts threaten more than 80,000 science scholarships. Nature 572: 575-576. DOI: https:// doi.org/10.1038/d41586-019-02484-w

ANGELO, C., 2019. Brazil's government freezes nearly half of its science spending. Nature 568(7751): 155-156. DOI: https://doi. org/10.1038/d41586-019-01079-9

ANTWIKI, 2019. Available from: www.antwiki.org/wiki/Welcome to AntWiki. Accessed on: Oct. 26, 2019.

BACCARO, F. B., R. M. FEITOSA, F. FERNANDEZ, I. O. FERNANDES, T. J. IZZO, J. L. P. SOUZA \& R. SOLAR, 2015. Guia para os gêneros de formigas do Brasil. Editora INPA, Manaus. DOI: https://doi.org/10.5281/zenodo.32912.

BARLOW, J., J. M. SILVEIRA, L. A. MESTRE, R. B. ANDRADE, G. C. D'ANDREA, J. LOUZADA \& M. A. COCHRANE, 2012. Wildfires in bamboo-dominated Amazonian forest: impacts on above-ground biomass and biodiversity. PLoS One 7(3): e33373. DOI: https://doi. org/10.1371/journal.pone.0033373.

BERNARDE, P. S., 2012. Serpentes peçonhentas e acidentes ofídicos no Acre: 1. ed.: 1-112. Anolis Books, Curitiba.

BERNARDE, P. S., L. C. B. TURCI \& R. A. MACHADO, 2017. Serpentes do Alto Juruá, Acre - Amazônia brasileira: 1. ed.: 1-165. EDUFAC, Rio Branco.

BESTELMEYER, B. T., D. AGOSTI, L. E. ALONSO, C. R. F BRANDÃO, W. L. BROWN, J. H. C. DELABIE \& R. SILVESTRE, 2000. Field techniques for the study of ground dwelling ants: an overview, description, and evaluation. In: D. AGOSTI, J. D. MAJER, L. E. ALONSO \& T. R. SCHULTZ (Ed.): Ants: standard methods for measuring and monitoring biodiversity: 122-144. Smithsonian Institution Press, Washington and London.

BIVAND, R., T. KEITT \& B. ROWLINGSON, 2019. Rgdal: bindings for the 'geospatial' data abstraction library. R package version 1.48. Available from: https://CRAN.R-project.org/package=rgdal. Accessed on: Oct. 26, 2019.

BOLTON, B., 2020. An online catalog of the ants of the world Available from: http://antcat.org. Accessed on: Oct. 28, 2019.

BRANDÃO, C. R. F., R. M. FEITOSA, F. A. SCHMIDT \& R. SOLAR, 2008. Rediscovery of the putatively extinct ant species Simopelta minima (Brandão) (Hymenoptera, Formicidae), with a discussion on rarity and conservation status of ant species. Revista Brasileira Entomologia 52(3): 480-483. DOI: https://doi.org/10.1590/S008556262008000300026
BROWN, G. R. \& I. M. MATTHEWS, 2016. A review of extensive variation in the design of pitfall traps and a proposal for a standard pitfall trap design for monitoring ground-active arthropod biodiversity. Ecology and Evolution 6(12): 3953-3964. DOI: https://doi. org/10.1002/ece3.2176.

COSTA, M. M. S., 2018. Como a cobertura florestal influencia as assembleias de formigas em escala de paisagem? Dissertação (Mestrado em Ecologia e Manejo de Recursos Naturais) Universidade Federal do Acre, Rio Branco.

DALY, D. C. \& M. SILVEIRA, 2008. Primeiro catálogo da flora do Acre, Brasil. EDUFAC, Rio Branco.

DE ANDRADE, M. L. \& C. B. URBANI, 1999. Diversity and adaptation in the ant genus Cephalotes, past and present. Stuttgarter Beiträge zur Naturkunde. Serie B Geologie und Paläontologie 271: 1-889.

DENICOL, M. R., 2014. Efeitos da sucessão florestal e da estrutura da vegetação sobre a fauna de formigas arborícolas (Hymenoptera: Formicidae). Dissertação (Mestrado em Ecologia e Manejo de Recursos Naturais) - Universidade Federal do Acre, Rio Branco.

DEL TORO, I., R. R. RIBBONS \& S. L. PELINI, 2012. The little things that run the world revisited: a review of ant-mediated ecosystem services and disservices (Hymenoptera: Formicidae). Myrmecological News 17: 133-146.

DRUMOND, P. M. (Org.), 2005. Fauna do Acre: 1-203. EDUFAC, Rio Branco.

DUNN, R. R., N. J. SANDERS, M. C. FITZPATRICK, E. LAURENT, J.-P. LESSARD, D. AGOSTI, A. N. ANDERSEN, C. BRUHL, $X$. CERDA, A. M. ELLISON, B. L. FISHER, H. GIBB, N. J. GOTELLI, A. GOVE, B. GUENARD, M. JANDA, M. KASPARI, J. T. LONGINO, J. MAJER, T. P. MCGLYNN, S. B. MENKE, C. L. PARR, S. M. PHILPOTT, M. PFEIFFER, J. RETANA, A. V. SUAREZ \& H. L. VASCONCELOS, 2007. Global ant (Hymenoptera: Formicidae) biodiversity and biogeography - a new database and its possibilities. Myrmecological News 10: 77-83.

FICK, S. E. \& R. J. HIJMANS, 2017. WorldClim 2: new 1-km spatial resolution climate surfaces for global land areas. International Journal of Climatology 37(12): 4302-4315. DOI: https://doi.org/10.1002/ joc.5086.

FONTENELE, L. K., 2018. Efeitos da transição floresta-pastagem e da dinâmica de fragmentação sobre a assembleia de formigas removedoras de sementes na Amazônia ocidental. Dissertação (Mestrado em Ecologia e Manejo de Recursos Naturais) Universidade Federal do Acre, Rio Branco.

GUILHERME, E., 2016. Aves do Acre: 1. ed.: 1-897. EDUFAC, Rio Branco. 
HIJMANS, R. J., J. VAN ETTEN, M. SUMNER, J. CHENG, A. BEVAN, R. BIVAND, L. BUSETTO, M. CANTY, D. FORREST, A. GHOSH, D. GOLICHER, J. GRAY, J. A. GREENBERG, P. HIEMSTRA, K. HINGEE, INSTITUTE FOR MATHEMATICS APPLIED GEOSCIENCES, C. KARNEY, M. MATTIUZZI, S. MOSHER, J. NOWOSAD, E. PEBESMA, O. P. LAMIGUEIRO, E. B. RACINE, B. ROWLINGSON, A. SHORTRIDGE, B. VENABLES \& R. WUEEST, 2019. Raster: geographic data analysis and modeling. $\mathrm{R}$ package version 3.0-12. Available from: https://CRAN.R-project. org/package= raster. Accessed on: Oct. 26, 2019.

INSTITUTO NACIONAL DE PESQUISAS ESPACIAIS (INPE), 2019. Projeto PRODES - monitoramento da floresta amazônica por satélite. Available from: http://www.obt.inpe.br/OBT/assuntos/ programas/amazonia/prodes. Accessed on: Oct. 26, 2019.

JANICKI, J., N. NARULA, M. ZIEGLER, B. GUÉNARD \& E. P. ECONOMO, 2016. Visualizing and interacting with large-volume biodiversity data using client-server web-mapping applications: the design and implementation of antmaps.org. Ecological Informatics 32: 185-193. DOI: https://doi.org/10.1016/j.ecoinf.2016.02.006.

KEMPF, W. W., 1968. Miscellaneous studies on Neotropical ants. IV. (Hymenoptera, Formicidae). Studia Entomologica 11: 369-415.

LEGENDRE, P. \& L. F. LEGENDRE, 2012. Numerical ecology: v. 24. Elsevier, New York.

LEWINSOHN, T. M. \& P. I. PRADO, 2005. Biodiversidade brasileira: sintese do estado atual do conhecimento. In: T. M. LEWINSOHN \& P. I. PRADO (Ed.): Síntese do conhecimento atual da biodiversidade brasileira: v. 1: 21-112. Contexto, São Paulo.

MAPBIOMAS, 2019. Coleções MapBiomas. Available from: http:// mapbiomas.org/pages/database/mapbiomas_collection. Accessed on: Nov. 17, 2019.

MENEZES, A. B., 2017. Mirmecofauna de áreas com diferente densidade de bambu no Parque Estadual Chandless, Alto Purus, Acre, Brasil. Monografia (Graduação em Engenharia Florestal) Universidade Federal do Acre, Rio Branco.

MENEZES, A. S. O., 2017. Mecanismos de coexistência de espécies e diversidade funcional em assembleias de formigas no Sudoeste da Amazônia brasileira. Dissertação (Mestrado em Ecologia e Manejo de Recursos Naturais) - Universidade Federal do Acre, Rio Branco..

MIRANDA, P. N., M. A. OLIVEIRA, F. B. BACCARO, E. F. MORATO \& J. H. C. DELABIE, 2012. Check list of ground-dwelling ants (Hymenoptera: Formicidae) of the eastern Acre, Amazon, Brazil. Check List 8(4): 722-730. DOI: http://dx.doi.org/10.15560/8.4.722.

MIRANDA, P. N., E. F. MORATO, M. A. OLIVEIRA\&J. H. C. DELABIE, 2013. A riqueza e composição de formigas como indicadores dos efeitos do manejo florestal de baixo impacto em floresta tropical no estado do Acre. Revista Árvore 37(1): 163-173. DOI: https://doi. org/10.1590/S0100-67622013000100017.
MIRANDA, P. N., F. B. BACCARO, E. F. MORATO, M. OLIVEIRA \& J. H. C. DELABIE, 2017. Limited effects of low-intensity forest management on ant assemblages in southwestern Amazonian forests. Biodiversity and Conservation 26: 2435-2451. DOI: https://doi. org/10.1007/s10531-017-1368-y.

MIRANDA, P. N., J. E. L. SILVA RIBEIRO, P. LUNA, I. BRASIL, J. H. C. DELABIE \& W. DÁTTILO, 2019. The dilemma of binary or weighted data in interaction networks. Ecological Complexity 38: 1-10. DOI: https://doi.org/10.1016/j.ecocom.2018.12.006.

OKSANEN, J., F. G. BLANCHET, M. FRIENDLY, R. KINDT, P. LEGENDRE, D. MCGLINN, P. R. MINCHIN, R. B. O'HARA, G. L. SIMPSON, P. SOLYMOS, M. H. H. STEVENS, E. SZOECS \& H. WAGNER, 2019. Vegan: community ecology package. $R$ package version 2.5-6. Available from: https://CRAN.R-project.org/ package=vegan. Accessed on: Nov. 17, 2019.

OLIVEIRA, A. B. S. \& F. A. SCHMIDT, 2019. Ant assemblages of Brazil nut trees Bertholletia excelsa in forest and pasture habitats in the Southwestern Brazilian Amazon. Biodiversity and Conservation 28(2): 329-344. DOI: doi.org/10.1007/s10531-018-1657-0.

OLIVEIRA, M. A., T. M. C. DELLA LUCIA, C. G. S. MARINHO, J. H. C. DELABIE \& E. F. MORATO, 2009. Ant diversity in an area of the amazon forest in Acre, Brazil. Sociobiology 54(1): 243-268.

OLIVEIRA, M. A., T. M. C. DELLA LUCIA, E. F. MORATO, M. A. AMARO \& C. G. MARINHO, 2011. Vegetation structure and richness: effects on ant fauna of the Amazon Acre, Brazil (Hymenoptera: Formicidae). Sociobiology 57(3): 243-267.

PATRO, S. \& K. K. SAHU, 2015. Normalization: a preprocessing stage. arXiv preprint arXiv: 1503.06462.

PHILPOTT, S. M., I. PERFECTO, I. ARMBRECHT \& C. L. PARR, 2010. Ant diversity and function in disturbed and changing habitats. In: L. LACH, C. L. PARR \& K. L. ABBOTT (Ed.): Ant ecology: 137156. Oxford University Press, New York.

R DEVELOPMENT CORE TEAM, 2019. R: a language and environment for statistical computing. R Foundation for Statistical Computing, Vienna, Austria. Available from: https://www.R-project. org. Accessed on: Nov. 17, 2019.

RABELING, C., J. M. BROWN \& M. VERHAAGH, 2008. Newly discovered sister lineage sheds light on early ant evolution. Proceedings of the National Academy of Sciences of the United States of America 105(39): 14913-14917. DOI: https://doi. org/10.1073/pnas.0806187105.

RYDER WILKIE, K. T., A. L. MERTL \& J. F. A. TRANIELLO, 2007. Biodiversity below ground: probing the subterranean ant fauna of Amazonia. Naturwissenschaften 94(9): 725-731.

SALES, F. M. S. S., 2019. Assembleias de formigas como indicadoras do tipo do uso do solo no sudoeste da Amazônia brasileira. Monografia (Graduação em Engenharia Florestal) - Universidade Federal do Acre, Rio Branco.

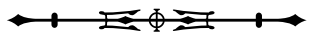


SANTOS, A. M., 2014. Riqueza e composição de formigas arborícolas (Hymenoptera: Formicidae) em floresta primária e secundária em um remanescente florestal, Acre. Monografia (Graduação em Engenharia Florestal) - Universidade Federal do Acre, Rio Branco.

SANTOS, R. S. \&J. H. C. DELABIE, 2018. Formigas epigéicas em um remanescente florestal no estado do Acre, Brasil e novos registros para o estado. Revista Brasileira de Agricultura 93(1): 24-32.

SCHMIDT, F. A., R. M. FEITOSA, R. F. MORAES \& R. S. JESUS, 2014. News on the enigmatic ant genus Anillidris (Hymenoptera: Formicidae: Dolichoderinae: Leptomyrmecini). Myrmecological News 19: 25-30.

SOUZA, M. B. D., M. SILVEIRA, M. R. M. LOPES, L. J. S. VIEIRA, E. GUILHERME, A. M. CALOURO \& E. F. MORATO, 2003. A biodiversidade no estado do Acre: conhecimento atual, conservação e perspectivas. T\&C Amazônia 1(3): 45-56.
SOUZA, M. B., 2009. Anfíbios: Reserva Extrativista do Alto Juruá e Parque Nacional da Serra do Divisor, Acre. Editora do Instituto de Filosofia e Ciências Humanas/UNICAMP, Campinas.

SILVA, W. R., 2017. Fauna de formigas em três tipos de habitat no sudoeste da Amazônia Brasileira. Monografia (Graduação emEngenharia Florestal) - Universidade Federal do Acre, Rio Branco.

UNIVERSIDADE FEDERAL DO ACRE (UFAC), 2020. Available from: www.ufac.br. Accessed on: Feb. 03, 2020.

WARD, P. S., 1999. Systematics, biogeography and host plant associations of the Pseudomyrmex viduus group (Hymenoptera: Formicidae), Triplaris and Tachigali-inhabiting ants. Zoological Journal of the Linnean Society 126(4): 451-540. DOI: https://doi. org/10.1006/zjls.1998.0158.

WILSON, E. O., 2003. Pheidole in the New World: a dominant, hyperdiverse ant genus. Harvard University Press, Cambridge. 
Appendix. List of ant species sampled in Acre, southwestern Brazilian Amazon, according to seven scientific papers and eight grey literature during the period of 2009 to 2019. S1 = Miranda et al. (2019); S2 = Oliveira, A. \& Schmidt (2019); S3 = Santos, R. \& Delabie (2018); S4 = Miranda et al. (2017); S5 = Miranda et al. (2013); S6 = Miranda et al. (2012); S7 = Oliveira, M. et al. (2009); S8 = Sales (2019); S9 = Costa (2018); S10 = Fontenele (2018); S11 = Menezes, A. B. (2017); S12 = Menezes, A. S. (2017); S13 = Silva (2017); S14= Denicol (2014); and S15 = Santos, A. (2014). S1-S7: scientific papers, S8-S15: grey literature.

(Continue)

\begin{tabular}{|c|c|c|c|c|c|c|c|c|c|c|c|c|c|c|c|}
\hline Taxa & S1 & $\mathrm{S} 2$ & S3 & S4 & S5 & S6 & S7 & S8 & S9 & $\mathrm{S} 10$ & S11 & $\mathrm{S} 12$ & S13 & S14 & $\mathrm{S} 15$ \\
\hline \multicolumn{16}{|l|}{ Dorylinae (19) } \\
\hline Acanthostichus femoralis Kusnezov, 1962 & & & & & & $x$ & $x$ & & & & & & & & \\
\hline Acanthostichus quadratus Emery, 1895 & & & & & & $x$ & $x$ & & & & & & & & \\
\hline Neocerapachys splendens (Borgmeier, 1957) & & & & & & x & $x$ & & & & & & & & \\
\hline Eciton burchellii (Westwood, 1842) & & & $x$ & & & $x$ & $x$ & & & & & & & & \\
\hline Eciton hamatum (Fabricius, 1782) & & & $x$ & & & $x$ & $x$ & & & & & & & & \\
\hline Eciton mexicanum Roger, 1863 & $x$ & & & $x$ & & $x$ & $x$ & & & & & & & & \\
\hline Eciton quadriglume (Haliday, 1836) & & & & & & $x$ & $x$ & & & & & & & & \\
\hline Eciton rapax Smith, 1855 & & & & & & $x$ & $x$ & & & & & & & & \\
\hline Eciton vagans (Olivier, 1792) & & & & & & & & & $x$ & & & & & & \\
\hline Labidus coecus (Latreille, 1802) & & & & $x$ & & $x$ & $x$ & & $x$ & & & & & $x$ & \\
\hline Labidus praedator (Smith, 1858) & & $x$ & & $x$ & & $x$ & $x$ & $x$ & $x$ & & & & $x$ & & \\
\hline Labidus spininodis (Emery, 1890) & & & $x$ & $x$ & & $x$ & $x$ & & & & & & & & \\
\hline Neivamyrmex carettei (Forel, 1913) & & & & & & $x$ & $x$ & & & & & & & & \\
\hline Neivamyrmex diana (Forel, 1912) & & & & & & $x$ & $x$ & & & & & & & & \\
\hline Neivamyrmex gibbatus Borgmeier, 1953 & & & & & & $x$ & $x$ & & & & & & & & \\
\hline Neivamyrmex orthonotus (Borgmeier, 1933) & & & & & & $x$ & $x$ & & & & & & & & \\
\hline Neivamyrmex pilosus (Smith, 1858) & & & & & & $x$ & $x$ & & & & & & & & \\
\hline Nomamyrmex esenbecki (Westwood, 1842) & & & & & & X & $x$ & & & & & & & & \\
\hline Nomamyrmex hartigii (Westwood, 1842) & & $x$ & & & & $x$ & $x$ & & & & & & $x$ & & \\
\hline \multicolumn{16}{|l|}{ Dolichoderinae (23) } \\
\hline Azteca chartifex Emery, 1896 & $x$ & & & $x$ & & $x$ & & & & & & & & & $x$ \\
\hline Azteca chartifex spiriti Forel, 1912 & & & & & & & $x$ & & & & & & & & \\
\hline Dolichoderus attelaboides (Fabricius, 1775) & $x$ & & $x$ & $x$ & & $x$ & $x$ & & $x$ & & $x$ & & & & $x$ \\
\hline Dolichoderus bidens (Linnaeus, 1758) & & $x$ & $x$ & $x$ & & $x$ & $x$ & $x$ & & & & & $x$ & $x$ & \\
\hline Dolichoderus bispinosus (Olivier, 1792) & $X$ & $X$ & & $x$ & & $x$ & $x$ & $x$ & $x$ & & $x$ & $x$ & $x$ & $x$ & \\
\hline Dolichoderus debilis Emery, 1890 & $X$ & & & & & & & & & & & & & $x$ & \\
\hline Dolichoderus decollatus Smith, 1858 & & & & $x$ & & $x$ & $x$ & & & & & & & & \\
\hline Dolichoderus diversus Emery, 1894 & & $x$ & & & $x$ & $x$ & X & & & & & & & $x$ & \\
\hline Dolichoderus ferrugineus Forel, 1903 & & & & $x$ & & $x$ & $x$ & & & & & & & & \\
\hline Dolichoderus gagates Emery, 1890 & & & & $x$ & & $x$ & $x$ & & & & & & & & \\
\hline Dolichoderus ghilianii Emery, 1894 & & & & & & $x$ & $x$ & & $x$ & & & & & $x$ & \\
\hline Dolichoderus imitator Emery, 1894 & & & & $x$ & & $x$ & $x$ & & $x$ & & $x$ & & $x$ & & \\
\hline
\end{tabular}


Appendix. (Continue)

\begin{tabular}{|c|c|c|c|c|c|c|c|c|c|c|c|c|c|c|c|}
\hline Taxa & S1 & S2 & S3 & S4 & S5 & S6 & S7 & S8 & S9 & $\mathrm{S} 10$ & S11 & $\mathrm{S} 12$ & $\mathrm{~S} 13$ & S14 & $\mathrm{S} 15$ \\
\hline Dolichoderus inermis MacKay, 1993 & & $x$ & & & & $x$ & $x$ & & & & & $x$ & $x$ & & \\
\hline Dolichoderus lamellosus (Mayr, 1870) & & $x$ & & & & & & & & & & & & & \\
\hline Dolichoderus lutosus (Smith, 1858) & & $x$ & & $x$ & & $x$ & $x$ & & & & & & & $x$ & \\
\hline Dolichoderus quadridenticulatus (Roger, 1862) & $x$ & & & & & $x$ & $x$ & & & & & & & $x$ & \\
\hline Dolichoderus rugosus (Smith, 1858) & & & & $x$ & & $x$ & $x$ & & $x$ & & $x$ & & & $x$ & \\
\hline Dolichoderus septemspinosus Emery, 1894 & $x$ & & & $x$ & & & & $x$ & & & & & & & \\
\hline Dolichoderus voraginosus MacKay, 1993 & & & & & & $x$ & $x$ & & & & & & & & \\
\hline Dorymyrmex brunneus Forel, 1908 & & $x$ & & & & & & $x$ & $x$ & $x$ & & $x$ & $x$ & & \\
\hline Gracilidris pombero Wild \& Cuezzo, 2006 & & $x$ & & & & & & $x$ & $x$ & & & & $x$ & & \\
\hline Linepithema neotropicum Wild, 2007 & & & & & & $x$ & $x$ & $x$ & $x$ & & & & & & \\
\hline Tapinoma melanocephalum (Fabricius, 1793) & & & & $x$ & & $x$ & & & & & & & $x$ & & $x$ \\
\hline
\end{tabular}

Ectatomminae (19)

Ectatomma brunneum Smith, 1858

Ectatomma edentatum Roger, 1863

Ectatomma lugens Emery, 1894

Ectatomma permagnum Forel, 1908

Ectatomma suzanae Almeida Filho, 1986

Ectatomma tuberculatum (Olivier, 1792)

Gnamptogenys acuminata (Emery, 1896)

Gnamptogenys annulata (Mayr, 1887)

Gnamptogenys concinna (Smith, 1858)

Gnamptogenys ericae (Forel, 1912)

Gnamptogenys falcifera Kempf, 1967

Gnamptogenys haenschi (Emery, 1902)

Gnamptogenys horni (Santschi, 1929)

Gnamptogenys mediatrix Brown, 1958

Gnamptogenys moelleri (Forel, 1912)

Gnamptogenys regularis Mayr, 1870

Gnamptogenys striatula Mayr, 1884

Gnamptogenys sulcata (Smith, 1858)

Gnamptogenys triangularis (Mayr, 1887)

\begin{tabular}{|c|c|c|c|c|c|c|c|c|c|c|c|c|c|}
\hline & $x$ & & & $x$ & $X$ & $x$ & $x$ & $X$ & $x$ & & $x$ & $x$ & \\
\hline & $x$ & & $x$ & & $x$ & & $x$ & $x$ & $x$ & $x$ & $x$ & $x$ & \\
\hline & $x$ & & $x$ & & $x$ & $x$ & & $x$ & $x$ & $x$ & $x$ & $x$ & $X$ \\
\hline & & & & $X$ & $X$ & $X$ & & & & & & & \\
\hline & & $x$ & $x$ & & $x$ & $x$ & & & & & & & \\
\hline$X$ & & & $x$ & $x$ & $x$ & $X$ & $x$ & $x$ & & $x$ & & $x$ & $X$ \\
\hline & $x$ & & $x$ & $x$ & $x$ & $X$ & & & & & & $x$ & \\
\hline & & & $x$ & & $x$ & $X$ & & & & & & & \\
\hline & $x$ & & & & & & & & & & & & $x$ \\
\hline & $x$ & & & & & & & $x$ & & & & $x$ & \\
\hline & & & & & $x$ & $x$ & & & & & & & \\
\hline & & & & & $x$ & $x$ & & & & & & & \\
\hline & & & $x$ & $x$ & $X$ & $x$ & & & & & & & $x$ \\
\hline & & & $x$ & $x$ & $X$ & & & & & & & & \\
\hline$x$ & & $x$ & & & & & & $X$ & & & & & \\
\hline & $X$ & & & & & & $x$ & $X$ & & & & $X$ & \\
\hline & $x$ & & $x$ & & $X$ & $x$ & & $X$ & & & & $X$ & \\
\hline$x$ & & $X$ & $x$ & $x$ & $X$ & $x$ & & & & & & & $X$ \\
\hline & & $x$ & & & & & & & & & & & \\
\hline
\end{tabular}

Formicinae (47)

Acropyga goeldii Forel, 1893

Acropyga guianensis Weber, 1944

Brachymyrmex admotus Mayr, 1887

Brachymyrmex cavernicola Wheeler, 1938

\begin{tabular}{ll|l|l|l|l|l|l|l|l|l|l|l|l}
$\times$ & & & & & & $\times$ & & & & & $\times$ & & \\
\hline & & & & $\times$ & $\times$ & & & & & & & & \\
\hline & & $\times$ & & $\times$ & $\times$ & & & & & & & & \\
\hline
\end{tabular}


Appendix.

Taxa

Brachymyrmex gaucho Santschi, 1917

Brachymyrmex heeri Forel, 1874

Brachymyrmex patagonicus Mayr, 1868

Brachymyrmex pilipes Mayr, 1887

Camponotus ager (Smith, 1858)

Camponotus apicalis (Mann, 1916)

Camponotus arboreus (Smith, 1858)

Camponotus atriceps (Smith, 1858)

Camponotus balzani Emery, 1894

Camponotus bidens Mayr, 1870

Camponotus blandus (Smith, 1858)

Camponotus cacicus Emery, 1903

Camponotus canescens Mayr, 1870

Camponotus cingulatus Mayr, 1862

Camponotus claviscapus Forel, 1899

Camponotus crassus Mayr, 1862

Camponotus depressus Mayr, 1866

Camponotus fastigatus Roger, 1863

Camponotus femoratus (Fabricius, 1804)

Camponotus godmani Forel, 1899

Camponotus heathi Mann, 1916

Camponotus hippocrepis Emery, 1920

Camponotus latangulus Roger, 1863

Camponotus leydigi Forel, 1886

Camponotus longipilis Emery, 1911

Camponotus mirabilis Emery, 1903

Camponotus nidulans (Smith, 1860)

Camponotus novogranadensis Mayr, 1870

Camponotus personatus Emery, 1894

Camponotus picipes guatemalensis Forel, 1885

Camponotus punctulatus andigenus Emery, 1903

Camponotus punctulatus minutior Forel, 1886

Camponotus rectangularis Emery, 1890

Camponotus renggeri Emery, 1894

Camponotus rufipes (Fabricius, 1775)

Camponotus senex (Smith, 1858)

\begin{tabular}{|c|c|c|c|c|c|c|c|c|c|c|c|c|c|c} 
S1 & S2 & S3 & S4 & S5 & S6 & S7 & S8 & S9 & S10 & S11 & S12 & S13 & S14 & S15 \\
\hline & & & $\times$ & $\times$ & $\times$ & $\times$ & & & & & & & & \\
\hline$\times$ & & & $\times$ & $\times$ & $\times$ & $\times$ & & & & & & & & \\
\hline & & & & & $\times$ & $\times$ & & & & & & & & \\
\hline
\end{tabular}

\begin{tabular}{|c|c|c|c|c|c|c|c|c|c|c|c|}
\hline & & & & $x$ & $x$ & & & & & & \\
\hline$x$ & & & & & & & & & $x$ & & \\
\hline$x$ & & & & & & $x$ & & & $x$ & $X$ & \\
\hline & & & & & & & & & & $X$ & \\
\hline & & & & & & & & $x$ & & $x$ & \\
\hline & $x$ & $x$ & $x$ & $x$ & $x$ & & $x$ & $x$ & $X$ & $x$ & $x$ \\
\hline & & & & & & & & & & $x$ & \\
\hline
\end{tabular}

\begin{tabular}{|c|c|c|c|c|c|c|c|c|c|c|c|c|}
\hline & & & & & & & & & & & $x$ & \\
\hline \multirow[t]{4}{*}{$X$} & $X$ & & & $x$ & $X$ & & & & & & & \\
\hline & $X$ & & & $x$ & $X$ & $X$ & $X$ & & $x$ & $X$ & & \\
\hline & & $x$ & $x$ & $x$ & $X$ & $x$ & $x$ & & & & $x$ & \\
\hline & & & $x$ & & & & & & & & & \\
\hline \multirow[t]{3}{*}{$x$} & & & & & & & & & & & & \\
\hline & & & $x$ & $x$ & & & & & & & & \\
\hline & $x$ & & $x$ & $x$ & $x$ & $x$ & $x$ & & & $x$ & & \\
\hline$x$ & $x$ & & $x$ & $x$ & $x$ & $x$ & $x$ & $x$ & $x$ & $x$ & $x$ & $x$ \\
\hline
\end{tabular}

\begin{tabular}{|c|c|c|c|c|c|c|c|c|c|c|c|c|c|}
\hline$x$ & $x$ & & $x$ & & $X$ & $X$ & $x$ & $x$ & $X$ & $x$ & $X$ & $x$ & $X$ \\
\hline & & $X$ & & $x$ & $x$ & $x$ & & & & & & & \\
\hline$x$ & & & $x$ & & $x$ & $x$ & & $x$ & & & & & \\
\hline$x$ & & & & & & & & & & & & & \\
\hline & & & & & & & & & & $x$ & & & \\
\hline
\end{tabular}

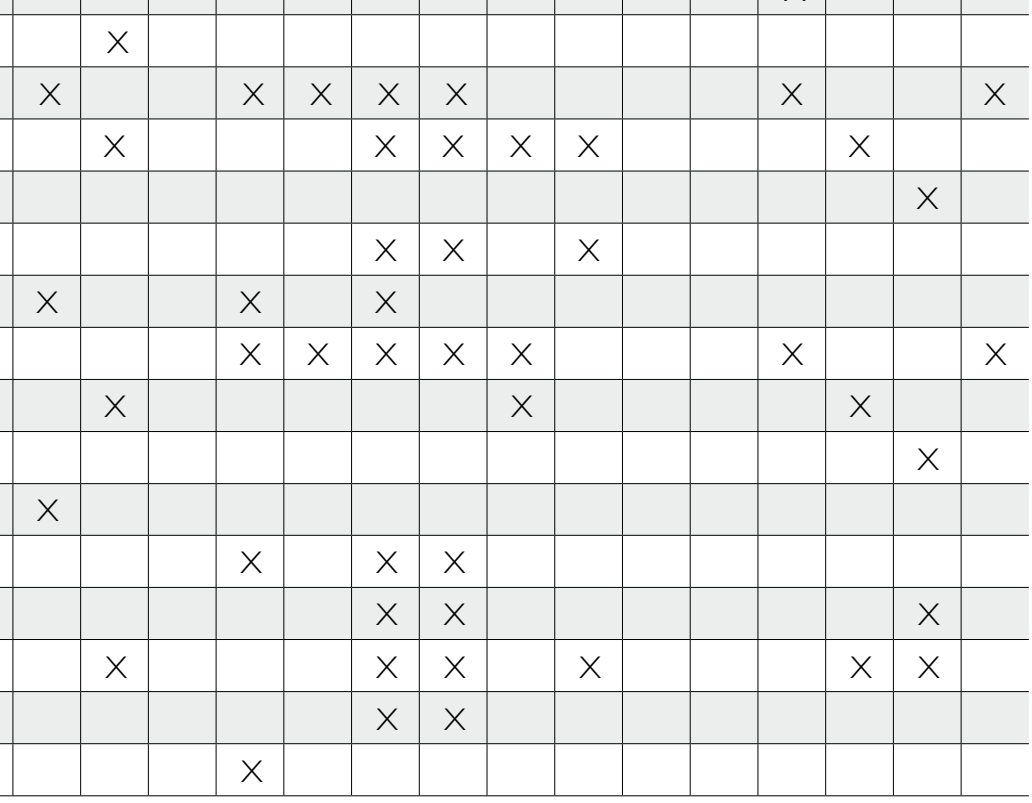


Appendix. (Continue)

\begin{tabular}{|c|c|c|c|c|c|c|c|c|c|c|c|c|c|c|c|}
\hline Taxa & S1 & S2 & S3 & S4 & S5 & S6 & S7 & S8 & 59 & $S 10$ & $\mathrm{~S} 11$ & $\mathrm{~S} 12$ & $\mathrm{~S} 13$ & S14 & S15 \\
\hline Camponotus sericeiventris (Guérin-Méneville, 1838) & & & & X & & X & X & & X & & & & & & \\
\hline Camponotus sexguttatus (Fabricius, 1793) & X & & & & & $x$ & $x$ & & & & & & & & \\
\hline Camponotus trapezoideus Mayr, 1870 & & $x$ & & X & & $x$ & $x$ & & & & & & & & \\
\hline Gigantiops destructor (Fabricius, 1804) & X & $x$ & & $x$ & $x$ & $x$ & $x$ & & $x$ & $x$ & & $x$ & $x$ & $x$ & $x$ \\
\hline Nylanderia fulva (Mayr, 1862) & & & & X & $x$ & X & $x$ & & & & & & & & \\
\hline Nylanderia guatemalensis (Forel, 1885) & X & & & $x$ & $x$ & X & $x$ & & & & & & & & \\
\hline Paratrechina longicornis (Latreille, 1802) & & & & & & $x$ & $x$ & & & & & & & $x$ & \\
\hline
\end{tabular}

Acanthoponera mucronata (Roger, 1860)

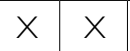

Myrmicinae (161)

Acromyrmex coronatus (Fabricius, 1804)

Acromyrmex subterraneus (Forel, 1893)

Allomerus octoarticulatus Mayr, 1878

Apterostigma acre Lattke, 1997

Apterostigma auriculatum Wheeler, 1925

Apterostigma megacephala Lattke, 1999

Apterostigma peruvianum Wheeler, 1925

Apterostigma turgidum Lattke, 1997

Atta cephalotes (Linnaeus, 1758)

Atta laevigata (Smith, 1858)

Atta sexdens (Linnaeus, 1758)

Basiceros militaris (Weber, 1950)

Carebara brevipilosa Fernández, 2004

Carebara urichi (Wheeler, 1922)

Cephalotes atratus (Linnaeus, 1758)

Cephalotes clypeatus (Fabricius, 1804)

Cephalotes complanatus (Guérin-Méneville, 1844)

Cephalotes cordatus (Smith, 1853)

Cephalotes cordiventris (Santschi, 1931)

Cephalotes cristatus (Emery, 1890)

Cephalotes maculatus (Smith, 1876)

Cephalotes marginatus (Fabricius, 1804)

Cephalotes minutus (Fabricius, 1804)

Cephalotes opacus Santschi, 1920

Cephalotes pallidoides De Andrade, 1999

Cephalotes pavonii (Latreille, 1809)

\begin{tabular}{|c|c|c|c|c|c|c|c|c|}
\hline$x$ & $x$ & & $x$ & $x$ & $x$ & & $x$ & $X$ \\
\hline & $x$ & & $x$ & & & & & \\
\hline & $x$ & & & & & & & \\
\hline & & $X$ & $X$ & $x$ & & & & \\
\hline & & & & & $x$ & & & \\
\hline & & & & & & $x$ & & \\
\hline
\end{tabular}

$\mid$

\begin{tabular}{|l|l|l|l|l|}
\hline & & $\times$ & & $X$ \\
\hline & & & & $X$ \\
\hline & & & & $X$ \\
\hline & & & & \\
\hline
\end{tabular}

\begin{tabular}{|l|l|l|} 
& & \\
\hline & & \\
\hline$\times$ & & $X$ \\
\hline
\end{tabular}

\begin{tabular}{|l|l|l|}
\hline & & $x$ \\
\hline & & $x$ \\
\hline$x$ & & \\
\hline
\end{tabular}

$x \quad x$

\begin{tabular}{c|c}
$x$ & $x$ \\
\hline & $x$
\end{tabular}

\begin{tabular}{|l|l|l|l|l}
\hline & & & & \\
\hline & & & & \\
\hline & & & & \\
\hline & & & & \\
\hline
\end{tabular}

\begin{tabular}{|c|c|}
\hline$x$ & $x$ \\
\hline$x$ & $x$ \\
\hline
\end{tabular}

\begin{tabular}{ll|l|l|l|l|l|l|l}
\hline & & & & $X$ & $X$ & & $X$ \\
\hline & & $X$ & & $X$ & & & \\
\hline & & & & & & & $X$ \\
\hline
\end{tabular}

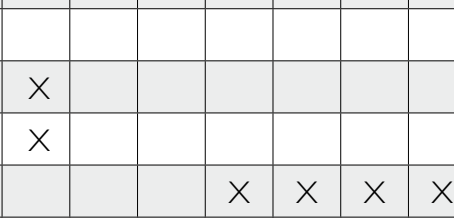

\begin{tabular}{|c|c|c|c|c|c|c|c|c|c|c|}
\hline & & & $x$ & $X$ & $x$ & $x$ & & & & \\
\hline$X$ & $x$ & $X$ & & $X$ & $x$ & & $x$ & $X$ & $X$ & $x$ \\
\hline & $x$ & $x$ & & $X$ & & & $x$ & & & \\
\hline & $x$ & & & & & & & & & \\
\hline & $x$ & & & & & & & $x$ & & \\
\hline & & & & & & & & & $X$ & \\
\hline & & & & & & & & & $X$ & \\
\hline & & $x$ & $x$ & $x$ & $X$ & $x$ & & & $X$ & $X$ \\
\hline$x$ & & & & & & & & & & \\
\hline
\end{tabular}

\begin{tabular}{c|l|l|l|l|l|l|l|l|l|l|l|l|l}
\multicolumn{1}{c|}{} & & $X$ & $X$ & $X$ & $X$ & & $X$ & & & & & $X$ & $X$ \\
\hline & & & & & & & & & & & & & \\
\hline
\end{tabular}


Appendix.

(Continue)

\begin{tabular}{|c|c|c|c|c|c|c|c|c|c|c|c|c|c|c|c|}
\hline Taxa & S1 & S2 & S3 & S4 & S5 & S6 & S7 & S8 & S9 & $\mathrm{S} 10$ & S11 & S12 & S13 & S14 & S15 \\
\hline Cephalotes pellans De Andrade, 1999 & & & & & & & & & & & & & & $x$ & \\
\hline Cephalotes pinelii (Guérin-Méneville, 1844) & X & & & & & & & & & & & & & & \\
\hline Cephalotes pusillus (Klug, 1824) & & & & & & X & X & & & & & & & & \\
\hline Cephalotes serraticeps (Smith, 1858) & & & $x$ & & & & & & & & & & & & \\
\hline Cephalotes spinosus (Mayr, 1862) & & & & $x$ & & X & X & & & & & & & X & $x$ \\
\hline Cephalotes umbraculatus (Fabricius, 1804) & & $x$ & & & & & & & & & & & & & \\
\hline Crematogaster brasiliensis Mayr, 1878 & X & $x$ & & X & & X & & & $x$ & & & $x$ & $x$ & & \\
\hline Crematogaster carinata Mayr, 1862 & $x$ & & & $x$ & & $x$ & & & $x$ & & & & & & \\
\hline Crematogaster crinosa Mayr, 1862 & & $x$ & & & $x$ & X & X & & & & & & & & \\
\hline Crematogaster curvispinosa Mayr, 1862 & $x$ & $x$ & & & & & & & & & & & & & \\
\hline Crematogaster dorsidens Santschi, 1925 & & & & & & & & & $x$ & & & & & & \\
\hline Crematogaster erecta Mayr, 1866 & $x$ & & & $x$ & & $x$ & $x$ & & & & & $x$ & & & \\
\hline Crematogaster evallans Forel, 1907 & & $x$ & & & & & & & & & & & & & \\
\hline Crematogaster flavosensitiva Longino, 2003 & $x$ & & & $x$ & & $x$ & & & $x$ & & & & & & \\
\hline Crematogaster jardinero Longino, 2003 & & & & & & & & & $x$ & & & & & & \\
\hline Crematogaster levior Longino, 2003 & & & & & & & & & $x$ & & & & & & \\
\hline Crematogaster limata Smith, 1858 & $x$ & & & $x$ & $x$ & X & $x$ & & $x$ & & & $x$ & & & \\
\hline Crematogaster longispina Emery, 1890 & $x$ & & & & & $x$ & $x$ & & $x$ & & & $x$ & & & \\
\hline Crematogaster moelleri Forel, 1912 & & $x$ & & & & & & & & & & & & & \\
\hline Crematogaster nigropilosa Mayr, 1870 & $x$ & & $x$ & & & $x$ & $x$ & & $x$ & & & $x$ & & & \\
\hline Crematogaster rochai Forel, 1903 & & X & & X & & X & $x$ & & & & & & & & \\
\hline Crematogaster sotobosque Longino, 2003 & & & & & & & & & & & & $x$ & & & \\
\hline Crematogaster stolli Forel, 1885 & & & & X & & $x$ & $x$ & & & & & & & & \\
\hline Crematogaster tenuicula Forel, 1904 & & x & $x$ & $x$ & $x$ & $x$ & $x$ & $x$ & & & & $x$ & $x$ & & \\
\hline Crematogaster torosa Mayr, 1870 & & x & & & & & & & & & & & & & \\
\hline Cyphomyrmex cornutus Kempf, 1968 & & & & & & $x$ & $x$ & & & & & & & & \\
\hline Cyphomyrmex laevigatus Weber, 1938 & & & & $x$ & & 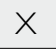 & X & $x$ & $x$ & & & & & & \\
\hline Cyphomyrmex major Forel, 1901 & & & & & $x$ & $x$ & $x$ & & & & & & & & \\
\hline Cyphomyrmex minutus Mayr, 1862 & & $x$ & & & & & & $x$ & $x$ & & & & $x$ & & \\
\hline Cyphomyrmex peltatus Kempf, 1966 & & & & $x$ & $x$ & $X$ & $x$ & & $x$ & & & & & & \\
\hline Cyphomyrmex rimosus (Spinola, 1851) & & $x$ & & & & & & $x$ & $x$ & & & & $x$ & & \\
\hline Cyphomyrmex salvini Forel, 1899 & & $x$ & & & & & & & & & & & $x$ & & \\
\hline Cyphomyrmex transversus Emery, 1894 & & & & $x$ & $x$ & $x$ & $x$ & & $x$ & & & & & & \\
\hline Cyphomyrmex vorticis Weber, 1940 & & & & & & & & & $x$ & & & & & & \\
\hline Daceton armigerum (Latreille, 1802) & & $X$ & & $x$ & & $x$ & $x$ & & & & & & & & \\
\hline Hylomyrma balzani (Emery, 1894) & & & & $x$ & $x$ & $x$ & $x$ & & & & & & & & \\
\hline
\end{tabular}


Appendix. (Continue)

Taxa

Hylomyrma immanis Kempf, 1973

Megalomyrmex ayri Brandão, 1990

Megalomyrmex balzani Emery, 1894

Megalomyrmex emeryi Forel, 1904

Megalomyrmex leoninus Forel, 1885

Megalomyrmex timbira Brandão, 1990

Megalomyrmex weyrauchi Kempf, 1970

Monomorium floricola (Jerdon, 1851)

Mycetarotes parallelus (Emery, 1906)

Mycetarotes senticosus Kempf, 1960

Mycetophylax faunulus (Wheeler, 1925)

Mycocepurus goeldii (Forel, 1893)

Mycocepurus smithii (Forel, 1893)

Ochetomyrmex neopolitus Fernández, 2003

Ochetomyrmex semipolitus Mayr, 1878

Octostruma balzani (Emery, 1894)

Octostruma betschi Perrault, 1988

Octostruma iheringi (Emery, 1888)

Oxyepoecus quadratus Albuquerque \&

Brandão, 2004

Pheidole aciculata Wilson, 2003

Pheidole araneoides Wilson, 2003

Pheidole astur Wilson, 2003

Pheidole biconstricta Mayr, 1870

Pheidole bruesi Wheeler, 1911

Pheidole bufo Wilson, 2003

Pheidole calimana Wilson, 2003

Pheidole capillata Emery, 1906

Pheidole cataractae Wheeler, 1916

Pheidole cramptoni Wheeler, 1916

Pheidole deima Wilson, 2003

Pheidole fallax Mayr, 1870

Pheidole fimbriata Roger, 1863

Pheidole fissiceps Wilson, 2003

Pheidole flavifrons Wilson, 2003

\begin{tabular}{|l|l|l|l|l|l|l|l|l|l|l|l|l|l|l} 
S1 & S2 & S3 & S4 & S5 & S6 & S7 & S8 & S9 & S10 & S11 & S12 & S13 & S14 & S15 \\
\hline
\end{tabular}

\begin{tabular}{|c|c|c|c|c|c|c|c|c|c|c|c|}
\hline & & & & & & $x$ & & & & & \\
\hline & & & $x$ & $X$ & $X$ & & & & & & \\
\hline & $x$ & & & $X$ & $x$ & & $x$ & $X$ & $x$ & $X$ & $x$ \\
\hline$x$ & & & $x$ & $x$ & & $x$ & $x$ & & & & \\
\hline & & $x$ & & & & $x$ & & & & & \\
\hline & & & & $X$ & $X$ & & & & & & $X$ \\
\hline
\end{tabular}

$\times \quad \times \quad \times$

\begin{tabular}{l|l|}
$X$ & $X$ \\
\hline & $x$
\end{tabular}

\begin{tabular}{l|l|l|l}
$X$ & $\times$ & $X$ \\
\hline
\end{tabular}

5)


Appendix.

Taxa

Pheidole fracticeps Wilson, 2003

Pheidole gagates Wilson, 2003

Pheidole gertrudae Forel, 1886

Pheidole horribilis Wilson, 2003

Pheidole infernalis Wilson, 2003

Pheidole jeannei Wilson, 2003

Pheidole jelskii Mayr, 1884

Pheidole lancifera Wilson, 2003

Pheidole leonina Wilson, 2003

Pheidole leptina Wilson, 2003

Pheidole lovejoy Wilson, 2003

Pheidole micridis Wilson, 2003

Pheidole oxyops Forel, 1908

Pheidole pedana Wilson, 2003

Pheidole polita Emery, 1894

Pheidole radoszkowskii Mayr, 1884

Pheidole schwarzmaieri Borgmeier, 1939

Pheidole scolioceps Wilson, 2003

Pheidole sensitiva Borgmeier, 1959

Pheidole stigma Wilson, 2003

Pheidole subarmata Mayr, 1884

Pheidole vafra Santschi, 1923

Pheidole vorax (Fabricius, 1804)

Pogonomyrmex abdominalis Santschi, 1929

Pogonomyrmex naegelii Emery, 1878

Procryptocerus convergens (Mayr, 1887)

Procryptocerus pictipes Emery, 1896

Rogeria belti Mann, 1922

Rogeria bruchi Santschi, 1922

Rogeria foreli Emery, 1894

Rogeria lirata Kugler, 1994

Sericomyrmex bondari Borgmeier, 1937

Sericomyrmex mayri Forel, 1912

Sericomyrmex parvulus Forel, 1912

Solenopsis geminata (Fabricius, 1804)

Solenopsis globularia (Smith, 1858)

\begin{tabular}{ll|l|l|l|l|l|l|l|} 
(Continue) \\
\hline
\end{tabular}

\begin{tabular}{|c|c|c|c|c|c|c|c|c|c|c|c|c|c|c} 
S1 & S2 & S3 & S4 & S5 & S6 & S7 & S8 & S9 & S10 & S11 & S12 & S13 & S14 & S15 \\
\hline & & & $\times$ & & $\times$ & & & & & & & & & \\
\hline & & & $\times$ & & $\times$ & $\times$ & & & & & & & & \\
\hline
\end{tabular}


Appendix. (Continue)

\begin{tabular}{|c|c|c|c|c|c|c|c|c|c|c|c|c|c|c|c|}
\hline Taxa & $\mathrm{S} 1$ & $\mathrm{~S} 2$ & S3 & S4 & S5 & S6 & S7 & S8 & S9 & $\mathrm{S} 10$ & S11 & $\mathrm{S} 12$ & $\mathrm{~S} 13$ & $\mathrm{~S} 14$ & S15 \\
\hline Solenopsis invicta Buren, 1972 & & & & $x$ & $x$ & $x$ & $x$ & & $x$ & $x$ & & $x$ & & & \\
\hline Solenopsis saevissima (Smith, 1855) & & & & & & & & & $x$ & $x$ & & $x$ & & & \\
\hline Solenopsis virulens (Smith, 1858) & & & & $x$ & & $x$ & $x$ & & & & & & & & $x$ \\
\hline Strumigenys alberti Forel, 1893 & & & & & & $x$ & $x$ & & & & & & & & \\
\hline Strumigenys appretiata (Borgmeier, 1954) & & & & $x$ & & $x$ & $x$ & & & & & & & & \\
\hline Strumigenys beebei (Wheeler, 1915) & & & & $x$ & & $x$ & $x$ & & & & $x$ & & & & \\
\hline Strumigenys depressiceps Weber, 1934 & & & & & & $x$ & $x$ & & & & & & & & \\
\hline Strumigenys eggersi Emery, 1890 & & & & $x$ & & X & & & $x$ & & & & & & \\
\hline Strumigenys elongata Roger, 1863 & & $x$ & & & & x & & & & & & & $x$ & & \\
\hline Strumigenys interfectiva Lattke e Goitía, 1997 & & & & & & & & & $x$ & & & & & & \\
\hline Strumigenys subedentata Mayr, 1887 & & & & $x$ & & x & $x$ & & & & & & & & \\
\hline Strumigenys trinidadensis Wheeler, 1922 & & & & $x$ & & $x$ & & & & & & & & & \\
\hline Strumigenys trudifera Kempf \& Brown, 1969 & & $x$ & & $x$ & & $x$ & & & & & & & $x$ & & \\
\hline Strumigenys zeteki (Brown, 1959) & & & & & & & & $x$ & & & & & & & \\
\hline Tetramorium bicarinatum (Nylander, 1846) & & & & & & $x$ & X & & & & & & & & \\
\hline Trachymyrmex bugnioni (Forel, 1912) & & $x$ & & & & & & $x$ & $x$ & & & & $x$ & & \\
\hline Trachymyrmex cornetzi (Forel, 1912) & & & & $x$ & $x$ & $x$ & $x$ & & & & & & & & \\
\hline Trachymyrmex farinosus (Emery, 1894) & & $x$ & & & $x$ & $x$ & $x$ & & & & $x$ & & $x$ & & \\
\hline $\begin{array}{l}\text { Trachymyrmex ixyodus Mayhé-Nunes \& } \\
\text { Brandão, } 2007\end{array}$ & & & & & & $x$ & x & & & & & & & & \\
\hline Trachymyrmex opulentus (Mann, 1922) & & & & $x$ & $x$ & $x$ & $x$ & & & & & & & & \\
\hline Trachymyrmex relictus Borgmeier, 1934 & & & & & & $x$ & $x$ & & $x$ & & & & & & \\
\hline Trachymyrmex ruthae Weber, 1937 & & & & $x$ & & $x$ & $x$ & & & & & & & & \\
\hline Tranopelta gilva Mayr, 1866 & & & & & & $x$ & $x$ & $x$ & $x$ & & & & $x$ & & \\
\hline Tranopelta subterranea (Mann, 1916) & & & & & & & & & $x$ & & & & & & \\
\hline Wasmannia auropunctata (Roger, 1863) & $x$ & $x$ & $x$ & $x$ & $x$ & $x$ & $x$ & $x$ & $x$ & & & $x$ & $x$ & $x$ & $x$ \\
\hline Wasmannia lutzi Forel, 1908 & & $x$ & & & & & & & & & & & $x$ & & \\
\hline Wasmannia rochai Forel, 1912 & & & & & & $x$ & $x$ & & & & & & & & \\
\hline Wasmannia sigmoidea (Mayr, 1884) & & & & & & & & & $x$ & & & & & & \\
\hline \multicolumn{16}{|l|}{ Paraponerinae (1) } \\
\hline Paraponera clavata (Fabricius, 1775) & & $x$ & & $x$ & & $x$ & $x$ & $x$ & $x$ & & & & $x$ & $x$ & $x$ \\
\hline \multicolumn{16}{|l|}{ Ponerinae (47) } \\
\hline Anochetus bispinosus (Smith, 1858) & & & & X & & $x$ & $x$ & & $x$ & & & & & & \\
\hline Anochetus diegensis Forel, 1912 & & & & $x$ & & $x$ & $x$ & & & & & & & & \\
\hline Anochetus targionii Emery, 1894 & & & & $x$ & & $x$ & & & & & & & & & \\
\hline Centromyrmex brachycola (Roger, 1861) & & & & & & $x$ & $x$ & & & & & & & & \\
\hline
\end{tabular}


Appendix.

(Continue)

\begin{tabular}{|c|c|c|c|c|c|c|c|c|c|c|c|c|c|c|c|}
\hline Taxa & S1 & S2 & S3 & S4 & S5 & S6 & S7 & S8 & S9 & S10 & $\mathrm{S} 11$ & $\mathrm{~S} 12$ & $\mathrm{~S} 13$ & S14 & S15 \\
\hline Cryptopone holmgreni (Wheeler, 1925) & & & & & & X & $x$ & & & & & & & & \\
\hline Leptogenys arcuata Roger, 1861 & & & & & & & & & $x$ & & & & & & \\
\hline Leptogenys gaigei Wheeler, 1923 & & & & & & & & & $x$ & & & & & & \\
\hline Leptogenys unistimulosa Roger, 1863 & & & & $x$ & & $x$ & $x$ & & & & & & & & \\
\hline Mayaponera constricta (Mayr, 1884) & & $x$ & $x$ & $x$ & $x$ & X & $x$ & $x$ & $x$ & $x$ & & & $x$ & & \\
\hline Neoponera apicalis (Latreille, 1802) & & & $x$ & $x$ & $x$ & $x$ & $x$ & & $x$ & & $x$ & & & $x$ & \\
\hline Neoponera carinulata (Roger, 1861) & $x$ & & & & & $x$ & $x$ & & & & & & & & \\
\hline Neoponera commutata (Roger, 1860) & & $x$ & $x$ & $x$ & & $x$ & $x$ & $x$ & & & & & $x$ & & \\
\hline Neoponera crenata (Roger, 1861) & & & & & & & & & $x$ & & & & & $x$ & \\
\hline Neoponera curvinodis (Forel, 1899) & & $x$ & & & & & & & & & & & & & \\
\hline Neoponera foetida (Linnaeus, 1758) & & & & & & $x$ & $x$ & & & & & & & & \\
\hline Neoponera globularia (MacKay \& MacKay, 2010) & & & & $x$ & & & & & & & & & & $x$ & \\
\hline Neoponera inversa (Smith, 1858) & & & & $x$ & & $x$ & $x$ & & & & & & & & \\
\hline Neoponera laevigata (Smith, 1858) & & & & $x$ & $x$ & $x$ & $x$ & & & & & & & & \\
\hline Neoponera marginata (Roger, 1861) & & & & & & $x$ & $X$ & & & & & & & & \\
\hline Neoponera metanotalis (Luederwaldt, 1918) & & & & & & & $x$ & & & & & & & $x$ & \\
\hline Neoponera moesta (Mayr, 1870) & & & & $x$ & & $x$ & & & & & & & & & $x$ \\
\hline Neoponera obscuricornis (Emery, 1890) & & $x$ & & $x$ & & & & $x$ & & $x$ & & & $x$ & & \\
\hline Neoponera striatinodis (Emery, 1890) & & & & & & & & & & & & & & $x$ & \\
\hline Neoponera unidentata (Mayr, 1862) & $x$ & & & $x$ & & $x$ & & & & & & & & $x$ & \\
\hline Neoponera verenae Forel, 1922 & & $x$ & $x$ & & $x$ & $x$ & $x$ & & $x$ & $x$ & $x$ & & $x$ & & \\
\hline Neoponera villosa (Fabricius, 1804) & & & & & & & & & & & & & & $x$ & $x$ \\
\hline Odontomachus bauri Emery, 1892 & & & $x$ & $x$ & $x$ & $x$ & $x$ & $x$ & $x$ & & & $x$ & & $x$ & \\
\hline Odontomachus biumbonatus Brown, 1976 & & & & $x$ & & $x$ & $x$ & & & & & & & & \\
\hline Odontomachus brunneus (Patton, 1894) & & $x$ & & & & $x$ & $x$ & & & & & & $x$ & & \\
\hline Odontomachus caelatus Brown, 1976 & & $x$ & $x$ & & & & & & & & $x$ & & $x$ & & \\
\hline Odontomachus chelifer (Latreille, 1802) & & & & $x$ & & $x$ & & & & & & & & & \\
\hline Odontomachus haematodus (Linnaeus, 1758) & $x$ & $x$ & $x$ & $x$ & $x$ & $x$ & $x$ & & $x$ & $x$ & & & $x$ & & \\
\hline Odontomachus hastatus (Fabricius, 1804) & $x$ & & & $x$ & & $x$ & & & & & & & & & \\
\hline Odontomachus laticeps Roger, 1861 & & & & & & & & & $x$ & $x$ & & & & & \\
\hline Odontomachus mayi Mann, 1912 & & & & & & $x$ & $x$ & & & & & & & & \\
\hline Odontomachus meinerti Forel, 1905 & & & & $x$ & $x$ & $x$ & $x$ & & $x$ & $x$ & & & & & \\
\hline Odontomachus opaciventris Forel, 1899 & & $x$ & & $x$ & & $x$ & & & & & & & $x$ & & \\
\hline Pachycondyla crassinoda (Latreille, 1802) & & $x$ & $x$ & $x$ & $x$ & $x$ & $x$ & $x$ & $x$ & $x$ & $x$ & $x$ & $x$ & & \\
\hline Pachycondyla harpax (Fabricius, 1804) & & $x$ & $x$ & $x$ & & $x$ & $x$ & $x$ & $x$ & $x$ & & & $x$ & & $x$ \\
\hline Pachycondyla impressa (Roger, 1861) & & & $x$ & & & & & & & & & $x$ & & & \\
\hline
\end{tabular}


Appendix.

Taxa

Platythyrea angusta Forel, 1901

Platythyrea sinuata (Roger, 1860)

Pseudoponera stigma (Fabricius, 1804)

Rasopone arhuaca (Forel, 1901)

Rasopone ferruginea (Smith, 1858)

Simopelta jeckylli (Mann, 1916)

Thaumatomyrmex zeteki Smith, 1944

Pseudomyrmecinae (19)

Pseudomyrmex atripes (Smith, 1860)

Pseudomyrmex curacaensis (Forel, 1912)

Pseudomyrmex elongatus(Mayr, 1870)

Pseudomyrmex ferrugineus (Smith, 1877)

Pseudomyrmex gracilis (Fabricius, 1804)

Pseudomyrmex laevigatus (Smith, 1877)

Pseudomyrmex niger (Donisthorpe, 1940)

Pseudomyrmex oculatus (Smith, 1855)

Pseudomyrmex oki (Forel, 1906)

Pseudomyrmex peruvianus (Wheeler, 1925)

Pseudomyrmex pupa (Forel, 1911)

Pseudomyrmex sericeus (Mayr, 1870)

Pseudomyrmex simplex (Smith, 1877)

Pseudomyrmex tenuis (Fabricius, 1804)

Pseudomyrmex termitarius (Smith, 1855)

Pseudomyrmex triplarinus (Weddell, 1850)

Pseudomyrmex unicolor (Smith, 1855)

Pseudomyrmex urbanus (Smith, 1877)

Pseudomyrmex venustus (Smith, 1858)

\begin{tabular}{|c|c|c|c|c|c|c|c|c|c|c|c|c|c|c|}
\hline S1 & S2 & S3 & S4 & S5 & S6 & S7 & S8 & S9 & $\mathrm{S} 10$ & S11 & $\mathrm{S} 12$ & $\mathrm{~S} 13$ & $\mathrm{~S} 14$ & $\mathrm{~S} 15$ \\
\hline & $x$ & & & & $x$ & $x$ & & & & & & & & \\
\hline & & & $X$ & & $x$ & $x$ & & & & & & & & \\
\hline & & & $X$ & & $x$ & & & & & & & & & \\
\hline & & & & & & & & $x$ & & & & & & \\
\hline & & & & & $x$ & $x$ & & & & & & & & \\
\hline & $x$ & & & & $x$ & $X$ & & & & & & $x$ & & \\
\hline & & & $X$ & & & & & & & & & & & \\
\hline & & & & & & & & & & & & & & \\
\hline & $x$ & & & & & & & & & & & & & \\
\hline & $x$ & & $X$ & & $x$ & $X$ & & & & & & & $x$ & \\
\hline & & & & & $X$ & $X$ & & & & & & & & \\
\hline & & & & $x$ & & & & & & & & & & \\
\hline & $x$ & & & & $X$ & $X$ & & $x$ & & & & & $x$ & $x$ \\
\hline & & & & & $x$ & $X$ & & & & & & & & \\
\hline & $x$ & & & & & & & & & & & & & \\
\hline$x$ & & & $X$ & & $x$ & $X$ & & & & & & & $x$ & \\
\hline & & & & & & & & & & & & & & $x$ \\
\hline & & & & & & & & & & & & & $x$ & \\
\hline & & & & & $X$ & $X$ & & & & & & & $x$ & \\
\hline & & & & & $X$ & $X$ & & & & & & & $x$ & \\
\hline & $x$ & & & & & & & & & & & $x$ & & \\
\hline$X$ & $x$ & & $X$ & & $X$ & $X$ & $X$ & $X$ & & $x$ & $x$ & $x$ & $x$ & $x$ \\
\hline & $X$ & & & & $X$ & $X$ & $X$ & $X$ & & & $X$ & $x$ & & \\
\hline & & & & & $x$ & & & $x$ & & & & & & \\
\hline & $x$ & & & & & & & & & & & & & \\
\hline & $x$ & & & & & & & & & & & $x$ & & \\
\hline & $x$ & & & & & & & & & & & & & \\
\hline
\end{tabular}

